\title{
Balancing the Scales of Justice: Do perceptions of buyers' justice drive suppliers' social performance?
}

\author{
Mohammad Alghababsheh* \\ School of Business \\ Mutah University \\ Alkarak \\ 61710 \\ Jordan \\ E-mail: m.alghababsheh@mutah.edu.jo
}

David Gallear

Brunel Business School

Brunel University London

Uxbridge

UB8 3PH

United Kingdom

E-mail: david.gallear@brunel.ac.uk

\author{
Mushfiqur Rahman \\ Brunel Business School \\ Brunel University London \\ Uxbridge \\ UB8 3PH \\ United Kingdom \\ E-mail: mushfiqur.rahman@brunel.ac.uk
}

* Corresponding author 


\title{
Balancing the Scales of Justice: Do perceptions of buyers' justice drive suppliers' social performance?
}

\begin{abstract}
A major challenge for supply chain managers is how to manage sourcing relationships to ensure reliable and predictable actions of distant suppliers. The extant research into sustainable supply chain management (SSCM) has traditionally focused on the transactional and collaboration approaches through which buyers encourage suppliers to act responsibly. However, little effort has been devoted to investigating the factors that underpin and enable effective implementation of these two approaches, or to exploring alternative approaches to help sustain an acceptable level of social performance from suppliers. Building on organisational justice theory, we developed a framework in which we propose that buyers' justice (i.e. distributive, procedural and interactional) as perceived by suppliers can serve as an alternative and complementary vehicle to the conventional sustainability governance approaches for driving the social justice exhibited by suppliers. The paper sheds new light on an alternative relational approach to help to restrain potentially harmful acts of suppliers. It provides a foundation for new research avenues in the SSCM context and supports more informed decision making by practitioners.
\end{abstract}

Keywords: Justice; Fairness; Supplier; Supply Chain; Sustainability; Responsible behaviour; Social Performance.

\section{Introduction}

Outsourcing to suppliers and establishing production networks in emerging markets have become increasingly popular strategies among organisations seeking to achieve cost savings or as a potential source of competitive advantage (Locke et al. 2009; Wagner and Johnson 2007). However, the shift from domestic purchasing strategy to international sourcing may not always achieve the desired goals due to reputational risks that can arise from internal unethical actions of suppliers, such as the use of child or forced labour and unfair payment practices (Spekman and Davis 2004; Joo et al. 2010). Under escalating pressure from customers, trade associations, nongovernmental organisations (NGOs) and from the fear of potential supply chain disruptions, organisations have turned to transactional and collaboration approaches as the means to help them sustain acceptable levels of suppliers' internal social performance (Klassen and Vereecke 2012; Sancha et al. 2016: Huq et al. 2016). The transactional approach (often perceived as arm's length) 
emphasises the use of socially sustainable transactional practices (SSTPs), for example certification and auditing, to increase supplier compliance to buyers' social requirements (Jiang 2009; Boyd et al. 2007). The collaboration approach focuses on the importance of socially sustainable collaboration practices (SSCPs), for example supplier development, to build suppliers' capabilities and improve overall sustainability performance (Seuring and Müller 2008; Klassen and Vereecke 2012; Huq et al. 2016).

Although conventional socially sustainable supply chain (SSSC) practices (SSTPs and SSCPs) have been hailed as important governance mechanisms for sustainable supply chains, mounting anecdotal and recent empirical evidence indicates that they may not effectively be helping buying organisations to maximise supplier compliance to social requirements (Sancha et al. 2016; Soundararajan and Brown 2016; Lund-Thomsen and Lindgreen 2014). In particular, the SSTPs are considered less likely to influence suppliers to sustain improvements in their working conditions and standards (Sancha et al. 2016; Locke et al. 2009; Lund-Thomsen 2008). It has been argued that monitoring and assessment tend to encourage suppliers to do just enough to meet threshold requirements (and hence avoid 'being caught') (Jiang 2009) and have even been associated with increases in the overall levels of violations by suppliers (Lim and Phillips 2008; Yu 2008). On the other hand, many organisations are reluctant to establish SSCPs with suppliers due to the high 'sustainability-specific' investment implementation costs (Lund-Thomsen and Lindgreen 2014) which can be magnified by suppliers' resistance and opportunistic behaviours (Touboulic and Walker 2015; Huq et al. 2014; Jiang 2009). Moreover, the narrower applicability of collaborative approaches to selected suppliers (Lund-Thomsen and Lindgreen 2014) and the generally long time needed to develop, implement and achieve the expected outcomes (Klassen and Vereecke 2012; Grosvold et al. 2014) has made SSCPs less attractive. Yet, despite the increasing recognition of the challenges associated with SSTPs and SSCPs, little attention has been devoted to understanding the factors that could enable their more effective implementation.

While the majority of the extant literature has traditionally focused on the SSTPs and SSCPs to address suppliers' existing social issues, minimising the likelihood of these issues occurring by eradicating their root causes has, surprisingly, been overlooked. Although suppliers' institutional or industrial conditions, for example weak regulations and high labour intensity respectively, can give rise to adverse social issues in their facilities (Huq et al. 2014; Crane 2013), it is often the case that these issues are also driven by buyers' unfair purchasing practices. To cope with continual cost reduction pressure from buyers, suppliers may feel forced to transfer part of the pressure to their workers by eroding workers' welfare, neglecting working condition improvement and using child labour (Jiang 2009; Awaysheh and Klassen 2010; Sancha et al. 
2016). Moreover, due to the regular technological breakthroughs, demand uncertainty, rapid changes in customer preferences and shrinking product life cycles in the modern marketplace, buyers are frequently requesting shorter lead times and higher flexibility (i.e. quality, quantity and mix) from suppliers. As a result, suppliers may either impose excessive overtime, or speed up production processes to levels beyond normal acceptable expectations of workers' physical ability to meet these requirements (Roth 2008; Yu 2008; Jiang 2009; Lund-Thomsen and Lindgreen 2014).

A growing amount of research has demonstrated the value derived from justice perception in buyer-supplier relationships (e.g. Kumar et al. 1995; Zaefarian et al. 2016; Poppo and Zhou 2014). Justice in buyer-supplier relationships is evidenced based on the extent to which distributive, procedural and interactional justice are established (Luo et al. 2015; Narasimhan et al. 2013). Ensuring fair procedures and interactions and equitably distributed returns between buyer and supplier can achieve desirable outcomes and facilitate the types of activities that are critical for the ongoing and effective functioning of the relationship (Kumar et al. 1995). Justice has, for example, been shown to enhance relationship quality (Muylle and Standaert 2016), satisfaction (Praxmarer-Carus et al. 2013), commitment (Zaefarian et al. 2016) trust (Hofer et al. 2012), innovation (Shockley and Turner 2016), cooperation (Wagner et al. 2011; Ling-yee 2010) and knowledge sharing (Liu et al. 2012) in the relationship. However, the significance of justice in enhancing the implementation of SSSC practices and in driving suppliers to establish social sustainability has largely been unexplored in sustainable supply chain management (SSCM) research to date. Although Boyd et al.'s (2007) study has advanced our understating of how procedural justice in corporate social responsibility (CSR) programmes may increase suppliers' compliance, our understanding of the potential role of distributive, procedural and interactional justice dimensions on the implementation of SSTPs and SSCPs and on suppliers' internal social performance is underdeveloped. It is this gap which the present study seeks to address. This gap persists despite recent research suggesting that each of the three dimensions of justice are essential and that a high level of one dimension will not compensate for a low level of another (Wang et al. 2014; Narasimhan et al. 2013) since each dimension may address different aspects of the buyer-supplier relationship, including economic, structural and social aspects (Lou et al. 2015). This study aims to address this gap by integrating the three justice dimensions into a holistic model that provides a better understanding of how each dimension can contribute to the implementation of SSTPs and SSCPs and to suppliers' internal social performance.

To achieve our aim, we draw on the relevant literature from SSCM and organisational justice theory to develop a conceptual framework in which we propose that buyer's justice (i.e. 
distributive, procedural and interactional) as perceived by suppliers can serve as an alternative and complementary vehicle to the conventional sustainability governance practices (i.e. SSTPs and SSCPs) in driving social justice exhibited by suppliers. Specifically, the framework first examines how SSTPs and SSCPs might influence supplier' internal social performance. It then disentangles how buyer's distributive, procedural, and interactional justice might individually and interactively drive supplier's internal social performance. Finally, the framework establishes the moderating effect of the three justice dimensions on the relationship between SSSC practices (i.e. SSTPs, SSCPs) and supplier's internal social performance. In doing so, our study addresses the research question: how can organisational buyer justice improve suppliers' internal social performance?

Our paper contributes to the supply chain management literature in two ways. First, this study highlights the centrality of buyers' justice in managing supply chain social issues. Specifically, the study proposes how buyers' distributive, procedural and interactional justice can lead to improvement in supplier' internal social performance. This extends the current literature, which has suggested that conventional practices such as certification (monitoring) and supplier development (collaboration) can be employed by buying firms to ensure the sustainability of their supply chains. Thus, this study represents a departure from the dominant conventional social sustainability governance approach by suggesting an alternative approach to managing supplier sustainability performance. Second, the study simultaneously investigates and disentangles the unique role of each of the three prominent justice dimensions in facilitating the implementation of SSTPs and SSCPs. Specifically, the study suggests a moderating effect of the justice dimensions on the relationship between SSSC practices and suppliers' internal social performance. Thus, this research proposes a complementarity effect through the three justice dimensions.

The paper develops as follows. In the next section a brief theoretical background on SSSC practices, suppliers' social performance and organisational justice is provided before our conceptual framework and associated propositions are developed. Following this, we outline our implications for theory and practice and identify future research directions.

\section{Theoretical background}

The existing literature that informs our conceptual development in this paper originates from two main perspectives. First, we examine the SSCM literature to identify and elaborate on the different SSSC practices and suppliers' internal social performance. Second, we discuss the organisational justice literature and provide a brief review of the current research on justice in buyer-supplier relationships. 


\section{Socially sustainable supply chain practices}

In the current literature the transactional and collaboration approaches have been identified as those governing supplier sustainability performance (Gimenez et al. 2012; Klassen and Vereecke 2012; Marshall et al. 2015; Sancha et al. 2016). These governance approaches have their specific assumptions and theoretical underpinnings. Accordingly, different mechanisms have been proposed under each approach to support or enhance suppliers' social performance, and a number of limitations associated with their use have been put forward. Table 1 summarises the main differences between the transactional and collaboration approaches.

\section{Insert Table 1 about here}

Based on Transaction Cost Economics (TCE) theory (Williams 1975), the transactional approach rests on the assumption that suppliers' social misconduct represents a form of opportunistic behaviour (Carter and Rogers 2008; Sancha et al. 2016). Grounded in this assumption, the transactional approach points to different socially sustainable transactional practices (SSTPs) through which a buying firm can assess, monitor, audit and seek to guide and control suppliers' behaviour relating to suppliers' working conditions, employee welfare and the elimination of the use of child labour (Jiang 2009; Klassen and Vereecke 2012; Huq et al. 2016; Sancha et al. 2016; Marshall et al. 2015). SSTPs are used to evaluate the extent to which suppliers conform to the societal expectations that are formulated in buyers' criteria (e.g. codes of conduct), stipulated in regulations or pre-specified in international standards (Ciliberti et al. 2009; Mamic 2005). They therefore constitute a process concerned with ensuring alignment between policy and practice (Grosvold et al. 2014). This requires formulating the assessment criteria and the collection and processing of information from suppliers and other involved parties (Gallear et al. 2012; Klassen and Vereecke 2012). The process can be accomplished by requesting that suppliers provide key performance indicator measures, complete a risk assessment relating to the current social conditions at their facilities (Sancha et al. 2015; Grosvold et al. 2014), or instigate an audit of their operations using a local independent third-party auditor (Huq et al. 2016). Verification of information provided by suppliers (Leire and Mont 2010) or by local auditors and government officials has, in light of corruption however, been noted to represent a major problem in the implementation of SSTPs (Jiang 2009 and Huq et al. 2014). Alternatively, buyers can carry out the monitoring and evaluation process by inspecting and auditing suppliers' progress using their own auditors or by employing their choice of a third-party auditor (Huq et al. 2016). Based on the outcome of this process, buying firms may warn or impose direct sanctions on violating suppliers, 
or offer incentives to compliant suppliers in the form of longer-term contracts and/or increased order volumes (Porteous et al. 2015; Andersen and Skjoett-Larsen 2009; Pedersen and Andersen 2006). In addition to helping to ensure supplier adherence to expectations, SSTPs may also help the buying firm to establish legitimacy by signalling its commitment towards social sustainability to a variety of stakeholders (Vurro et al. 2009; Boyd et al. 2007). Despite the perceived benefits however, it is also widely agreed that codes of conduct and other standards tend to be open to broad interpretation, are often accompanied by a lack of the involvement of the suppliers in the planning and setting of sustainability goals (Yawar and Seuring 2017) and lack of sharing of the implementation costs (Yu 2008), and moreover that they often ignore the culture and economic context in which suppliers operate (Huq et al. 2014; Ciliberti et al. 2009).

Grounded in the Relational View (RV) (Dyer and Singh 1998), the collaboration approach assumes that close collaboration with suppliers and other stakeholders (i.e. customers and NGOs) can significantly improve suppliers' social performance (Klassen and Vereecke 2012; Rodriguez et al. 2016). Collaboration builds a bridge between buyer and suppliers by opening up two-way dialogue that enables them jointly to address social issues (Jiang 2009; Klassen and Vereecke 2012). Unlike the transactional approach, the collaboration approach emphasises a longer-term view by enhancing and building suppliers' capabilities to manage social issues (Klassen and Vereecke 2012). Socially sustainable collabration practcies (SSCPs) typically include setting up supplier development and education programmes, sharing knowledge with suppliers, organizing meetings and conferences, awarding suppliers subsidies to obtain third-party certification, and jointly developing new products or processes that improve the health and safety of the employees (Jiang 2009; Gallear et al. 2012; Marshall et al. 2015; Klassen and Vereecke 2012; Porteous et al. 2015; Sancha et al. 2015). SSCPs can therefore be regarded as sustainability-specific assets, knowledge-sharing routines and complementary resources in buyer-supplier relationships (Dyer and Singh 1998).

Organisations may extend the collaborative reach beyond suppliers to include non-traditional supply chain actors such as civil societies and NGOs (Tencati et al. 2008; Rodriguez et al. 2016). Although collaborating with such actors - who are likely to have different strategies, organizational structures, and goals (e.g. non-profit) - can pose unique challenges (Pagell and Shevchenko 2014), they have been shown to play a vital role in the implementation of SSCPs by providing unique and complementary resources (Rodriguez et al. 2016; Gold et al. 2013; PerezAleman and Sandilands 2008; Tencati et al. 2008). The resources provided by actors such as NGOs, which usually take the form of bespoke (situation-specific) knowledge for tailoring supplier development programmes to match supplier needs and bridge capability gaps, 
complement buying firms' resources (e.g. knowledge transfer and logistical routines) to increase the effectiveness of the implementation of SSCPs.

Although the collaboration approach has been shown to positively affect suppliers' social performance, it has also been argued that in reality it may only be implementable with a limited number of suppliers due to the high associated implementation costs and the long time needed to develop, implement and achieve the expected outcomes (Klassen and Vereecke 2012; LundThomsen and Lindgreen 2014).

\section{Suppliers' internal social performance}

The shift from conventional supply chain management where the focus is on maximising economic value (Gunasekaran et al. 2004), to SSCM where the emphasis is on simultaneously sustaining economic, environmental and social performance (Carter and Rogers 2008; Seuring and Müller 2008) has further increased the complexity of measuring supply chain performance

(Beske-Janssen et al. 2015; Ahi et al. 2016). While measurement of the economic and environmental performance of supply chains is relatively advanced, the measurement of social performance is still very much underdeveloped (Hutchins and Sutherland 2008; Sarkis et al. 2010; Ahi and Searcy 2015). This, in part, can be attributed to the relative importance that has been attached to each type of performance and also to the nature of social performance per se. The majority of the extant research has followed the instrumental logic in which the economic performance of sustainable supply chain initiatives has been the primary focus of investigation (Gao and Bansal 2013; Montabon et al. 2016). Moreover, the majority of the extant research has also focused on environmental issues, arguably because they have been perceived to have the potential to make more wide ranging impact than social issues. As Montabon et al. (2016, p.15) noted, "All environmental issues have social consequences, but not all social issues are environmental". The general lack of agreement on the scope and nature of social issues in supply chains is another possible reason for social performance measurement's underdevelopment (Ahi and Searcy 2015). The lack of consensus is likely to be due to the fact that social issues reflect society's baseline expectations for improving human behaviour, which not only change over time but vary according to the culture in which the organisation and its suppliers are based (Awaysheh and Klassen 2010). Child labour, for example, is considered unacceptable in the vast majority of, if not all, Western countries, however it is viewed as an acceptable vehicle of family support and early training for children in a profession in some parts of Asia (Khan 2007; Lund-Thomsen and Lindgreen 2014). As a result, examining social performance in supply chains has received far less attention from both sustainability scholars and practitioners (Ahi and Searcy 2015; Beske-Janssen et al. 2015; Zorzini et al. 2015). 
Suppliers' social misconduct can have a detrimental impact on their employees' safety, health and welfare, and can extend to affecting the well-being of local communities and local customers (Klassen and Vereecke 2012). Accordingly, suppliers' social performance can be seen to encompass both an internal and an external dimension (Huq et al. 2016; Yawar and Seuring 2017). The external social performance relates to the support and well-being of the local communities within which the supplier operates (Huq et al. 2016). On the other hand, suppliers' internal social performance is associated with the working conditions, safety and healthcare, working hours, payment rates, disciplinary practices and child employment 'policies' adopted within the suppliers' premises (Yawar and Seuring 2017; Zorzini et al. 2015; Sancha et al. 2016; Awaysheh and Klassen 2010). In this paper, we focus on the internal social performance for two primary reasons. First, alongside macro factors related to the suppliers' environment (e.g. institutional, cultural and socio-economic factors) (Crane 2013), social responsibility deteriorations within suppliers' operations are also partly driven by buyers' unfair purchasing practices such as cost pressure, shortened lead times and exacting requirements for high flexibility (Barrientos 2013; Jiang 2009). Second, buying firms are more likely to implement SSSC practices (SSTPs and SSCPs) to improve the suppliers' internal social performance, as inadequate or reducing performance (for example adverse workplace incidents) has the potential to negatively affect suppliers' internal operations and hence cause supply chain disruptions for the buyer (Pullman et al. 2008; Rodriguez et al. 2016).

\section{Justice}

The theory of organisational justice has been extensively researched at an intra-organisational level (Fortin et al. 2016) which has traditionally focused on individuals' and groups' perception of workplace justice ( $\mathrm{Li}$ and Cropanzano 2009). It is only recently that justice theory has begun to receive interest at the inter-orgnisational level, including at the level of the supply chain (Zaefarian et al. 2016; Theodorakopoulos et al. 2015). In this context, research has started to emerge highlighting the role and outcomes of perception of justice in supply chain relationships. Table 2 provides a detailed analysis of the current empirical work that has examined justice in a supply chain relationship context. Justice is considered to be a foundation for supply chain relationships where each of its dimensions plays a unique and distinct role in sustaining the relationship (Trada and Goyal 2017; Yilmaz et al. 2004). Distributive justice is connected to the economic aspect of the relationship, procedural justice to the structural part of the relationship, and interactional justice is associated with the social side (Luo et al. 2015).

Insert Table 2 about here 
Distributive justice refers to the extent to which a supplier perceives the allocation of outcomes as proportional to the costs incurred from the relationship (Luo 2007a). This view is based on the logic of equity theory (Adams 1965), and advances that a supplier will compares its own ratio of perceived inputs to outcomes against that of the buyer. The comparison creates a perception of either equity or inequity. The supplier experiences an equity condition when it perceives that its outcomes-to-inputs ratio is equal to that of the buyer. In contrast, the supplier experiences an inequity condition when its ratio is perceived to be less than, or to exceed, that of the buyer (Greenberg 1982). However, the allocation of outcomes based on 'equality' or 'need' may also shape the perception of distributive justice in the relationship (Kashyap et al. 2008). Equalitybased distributive justice is perceived when the supplier receives comparable outcomes to that received by the buyer irrespective of their inputs, whereas need-based distributive justice is established when they obtain outcomes based on their known needs and regardless of their contributions (Deutsch 1975). The allocation of outcomes based on equity, equality or need, and thus determining the perception of distributive justice, in a given relationship depends on the primary aim of that relationship (Deutsch 1975). In business relationships (e.g. buyers-supplier), which is established mainly for economic productivity, equity rule will be the dominant rule in the allocation of outcomes, and thus shaping the perception of distributive justice in the relationship (Deutsch 1975). Accordingly, we use equity-based distributive justice in this paper as suppliers are more likely to use equity rule to evaluate the extent of distributive justice in the relationship.

Procedural justice refers to the degree to which a supplier perceives the procedures and policies that govern all relationship aspects as impartial (Blancero and Ellram 1997). Suppliers assess the fairness of the procedures relating to pricing, delivery, flexibility, product quality, responsibilities and resource allocations in the relationship (Kumar et al. 1995; Zaefarian et al. 2016; Wang et al. 2014). A supplier's perception of fair procedures is established when the procedures are deemed to be consistent, bias-free, accurate, correctable, ethical (Leventhal 1980) and conform to contractual specifications (Luo 2007a). Nevertheless, suppliers may not use all of the criteria to judge the fairness of a particular procedure, but instead might choose to allocate weights to and apply different criteria in different situations (Leventhal 1980).

Interactional justice refers to the extent to which a supplier perceives the interpersonal treatment and information received during the enactment of relationship procedures to be fair (Wang et al. 2014). Thus, interactional justice relates to the communication and interaction process between the buyer and supplier, and encompasses two aspects: interpersonal treatment and an informational aspect (Folger and Cropanzano 1998). With the interpersonal aspect, a higher 
perception of interactional justice is perceived as a result of buyers treating suppliers with respect, sensitivity, politeness and dignity (Liu et al. 2012). For the informational component, a higher perception of interactional justice is fostered when the supplier is provided with ample, timely and truthful justification and explanation behind a decision or an outcome (Colquitt 2001; Tyler and Bies 1990).

\section{Conceptual framework and propositions}

Our proposed conceptual framework establishes the relationship between socially sustainable supply chain (SSSC) practices, buyers' justice and suppliers' internal social performance (see Figure 1). The framework suggests that the implementation of socially sustainable transactional practices (SSTPs) has no impact on suppliers' internal social performance, while the implementation of socially sustainable collaboration practices (SSCPs) has a positive effect. The framework also proposes that higher perceptions of buyers' justice (i.e. distributive, procedural and interactional) are directly and positively related to suppliers' internal social performance. Furthermore, the framework predicts that perceptions of buyers' justice help to facilitate the effective implementation of SSSC practices. Specifically, that buyer justice dimensions positively moderate the relationship between SSSC practices and suppliers' internal social performance.

\section{Insert Figure 1 about here}

The proposed conceptualisation was the outcome of a literature review to analyse the prior research on SSCM and justice in buyer-supplier relationships. Our review followed the systematic database search process described in the systematic literature review methodology (Tranfield et al. 2003). We first developed a set of central keywords ("responsib*" OR "ethic*" OR "sustainab*” OR "social*” OR justice OR fairness AND “supply chain” OR "buyer-supplier" OR supplier OR purchasing OR sourcing) to search the literature based on the article title, abstract and keywords. Having located salient contributions we followed Greenhalgh and Peacock's (2005) advice and located further literature through cross-referencing. To ensure the comprehensiveness of our search, we employed a backward and forward snowballing technique (Webster and Watson, 2002). We then chronologically summarised these salient contributions and extracted a schema of relevant themes and observations within the assembled body of literature. As our content analysis proceeded, the conceptual framework emerged and continued to be refined until our review was complete. 
We formulate our propositions in the next three sections. The first section focuses on the relationship between SSSC practices (SSTPs and SSCPs) and suppliers' internal social performance. The second develops the relationship between buyers' justice dimensions and suppliers' internal social performance. Having presented the main effects, the third section establishes the moderating effects of buyers' justice dimensions on the relationship between SSSC practices and suppliers' internal social performance.

\section{SSSC practices and suppliers' internal social performance}

A number of scholars have questioned the way in which SSSC management has been claimed to impact performance, arguing that combining social and environmental dimensions into a single concept makes separate analysis impossible, and hence creates theoretical ambiguity as to whether pursuing social initiatives in the supply chain can lead to performance improvements for associated partners (e.g. Klassen and Vereecke 2012; Marshall et al. 2016; Sancha et al. 2015). As a result of this critique, a new research stream has recently started to develop focused exclusively on the social dimension in order to gain a clearer understanding of its performance implications (e.g. Klassen and Vereecke 2012; Sancha et al. 2015; Huq et al. 2016). Prior research considers suppliers' social performance improvement to be one of the essential goals of the implementation of SSSC practices. However, while attempts have been made to examine the impact of SSSC practices on buyers' and suppliers' economic performance (e.g. Hollos et al. 2012; Marshall et al. 2016), attempts to examine its impact on suppliers' social performance are rare (Sancha et al. 2015; Sancha et al. 2016; Huq et al. 2016).

In the SSTP approach, objectives are specified, performance is audited, feedback is provided, progress is monitored and rewards and punishments are administered to align suppliers' behaviour with buyers' social criteria (Klassen and Vereecke 2012; Porteous et al. 2015). The growing literature on the social dimensions along with significant anecdotal evidence suggests that SSTPs are less likely to lead to observable progress. In an analysis of social and green supply chain practices, Hollos et al. (2012) found that the social practices (certification and compliance) had no effect on cost reduction and the operational performance of suppliers. This outcome was also observed by Marshall et al. (2016), who found that the use of process-based practices (monitoring and auditing) had no influence on suppliers' performance. Yu (2008) examined the impact of the implementation of a code of conduct on labour standards (i.e. low-wage payment, freedom of association and collective bargaining) at Reebok's suppliers in Chain. Their findings from semi-structured interviews demonstrated that corporate social responsibility (CSR) policy and the code of conduct were ineffective in addressing the social issues, and had even been related to an increase in the overall level of violations by suppliers. Huq et al. (2014) observed 
that buyers' monitoring and enforcement of a code of conduct can drive suppliers to hide workplace violations and instead pursue 'mock' compliance behaviours. Similarly, using data from non-compliant and compliant Chinese apparel and textile suppliers, Jiang (2009) revealed that buyer-to-supplier governance (i.e. auditing and monitoring) had no effect on supplier compliance to codes of conduct. More recently, in what appears to be the first dedicated examination of suppliers' social performance, Sancha et al. (2016) found that the use of assessment practices by buying firms were not effective in enhancing suppliers' social performance. Based on the above arguments we propose the following:

Proposition 1a There is no relationship between SSTPs and suppliers' internal social performance.

Unlike SSTPs, SSCPs aim to reverse deteriorations in suppliers' social performance by investing in enhancing their capabilities and opening up new market opportunities by developing new product and services (Marshall et al. 2015; Huq et al. 2016). In addition to their positive impact on the economic performance of supply chain members (Klassen and Vereecke 2012), SSCPs have been shown to drive social improvements in suppliers' employee welfare (Sancha et al. 2016). Collaboration facilitates the formation of interaction routines that enable the exchange of assets and knowledge for the tangible and effective improvement of environmental and social performance throughout the supply chain (Gualandris and Kalchschmidt 2016). Based on the resource-based view (Barney 1991), Sancha et al. (2015) found that buyer-supplier social sustainability joint-efforts and training sessions promote mutual learning and knowledge exchange, enabling suppliers to build specific capabilities to improve their social performance. Likewise, Jiang (2009) found that close collaboration between buyer and supplier through training and incentives increases suppliers' compliance with codes of conduct. Sancha et al. (2016) found evidence that buyers' direct collaborative involvement with and sustainability investments in suppliers increased their compliance with human rights, reduced child labour employment and improved safety and labour conditions. In their longitudinal study of multinational buyers and their developing country suppliers, Huq et al. (2016) discovered that buyers establish the foundation for improved social conditions and hence suppliers' internal and external social performance, by collaborating with suppliers rather than using third-party auditors. Training for suppliers is strongly associated with a reduction in suppliers' environmental and social violations and buyers' operating costs (Porteous et al. 2015). These arguments provide clear support for the effectiveness of the collaborative approach, leading us to propose the following: 
Proposition 1b There is a positive relationship between SSCPs and suppliers' internal social performance.

\section{Buyers' justice and suppliers' internal social performance}

Buyers, in general, continually tend to demand price reductions, non-cost related payments, discounts, quality improvements or extended payment terms and warranty periods (Fearne et al. 2005; Henke et al. 2008) from their suppliers, all of which represent an extra cost to the supplier. These often unethical exploitations of suppliers are commonly attributed to buyers' bargaining power (Fassin 2005). Suppliers might depend on particular buyers because a high proportion of their goods or services are purchased by those buyers. If the buyer threatens to switch to a different supplier to gain a price reduction, the potential consequences of losing the buyer might be more detrimental to the supplier than if it accepted the price reductions (Schleper et al. 2017). This creates a perception of negative inequity, which in turn increases the supplier's resentment, and subsequently increases its motivation/likelihood to seek to reduce the perceived inequity by enhancing output through opportunistic behaviours (Adams 1965; Brown et al. 2000). When a supplier is less powerful than the source of the perceived inequity (the buyer) attempts to restore equity will be largely indirect (Homans 1961). The supplier may seek to reduce costs by repeatedly passing cost savings on to workers by eroding their welfare, reducing investments in their working conditions or even by employing child labour in their facilities (Jiang 2009; Awaysheh and Klassen 2010). These violations of the social obligations and expectations represent various forms of negative opportunistic behaviours by the supplier (Sancha et al. 2016). Thus, a buyer's unfair practices can in turn lead to a supplier's unfair relationship with its workers. Conversely, a fair distribution of benefits in supply chain relationships can reduce a supplier's motivation to behave opportunistically in this way (Luo et al. 2015). Perceptions of higher distributive justice enhance suppliers' confidence in the fairness of future benefit and revenue allocation (Luo et al. 2015). Fair treatment in outcome distribution also removes fear of exploitation and can stimulate transparency (Luo 2007b). Therefore, if suppliers receive a proportional return for their efforts from buyers, they will be able to invest in improving workplace infrastructures and delivering fair payment to their workers, and they will be less likely to seek cost savings by employing child labour. Based on the above discussion we propose the following:

Proposition 2a Buyers' distributive justice is positively related to suppliers' internal social performance.

To deal with demand uncertainty, escalating customer expectations and shrinking product life cycles, buyers may place orders with suppliers demanding unrealistic delivery times or with 
volatile (changing) order volumes (Barrientos 2013). Making changes to contractual arrangements and unreasonably transferring risk to the supplier is an indication of unfair procedures (Fearne et al. 2005) since it violates the consistency criterion that shapes the perception of fair procedures. Vulnerable suppliers often have no option but to fulfil orders by adopting 'hidden' tactics to keep contracts and protect their own interests rather than seeking direct negotiation (or confrontation) with more powerful buyers (Liu et al. 2017; Brown et al. 1995). They may consequently either force excessive overtime or accelerate production processes to a level that is beyond what is acceptable for workers' normal physical ability (Yu 2008; LundThomsen and Lindgreen 2014). Workers are pushed to perform tasks faster, creating unmanageable work overloads which in turn increase the likelihood of adverse workplace incidents (Wiengarten and Longoni 2018). Conversely, stability and consistency in buyers' implementation of relationship procedures and policies reduces risk and increases suppliers' belief that its interests are protected and valued, which in turn increases commitment and longterm orientation (Johnson et al. 2002; Griffith and Lusch 2000). Perceptions of high procedural justice enhance suppliers' belief that important decisions will be reached by mutual recognition (Luo 2008). A high level of procedural justice helps ensure high levels of supplier social compliance by communicating to each supplier that they are valued by the buying company as an exchange partner (Boyd et al. 2007). Procedural justice improves rule compliance by increasing adherence to the guidelines that govern a relationship (Colquitt 2001; Aquino 1995). Therefore, buyers' procedural justice is likely to lead to suppliers being less likely to engage in social misconduct practices (Huo et al. 2016; Luo 2007b). Based on these arguments we propose the following:

Proposition 2b Buyers' procedural justice is positively related to suppliers' internal social performance.

Also to deal with demand uncertainty, heightened customer expectations and shrinking product life cycles, buyers may delay placing orders until very late, creating unrealistic and difficult to fulfil delivery expectations. Although most suppliers are likely to be understanding of the need for changes to relationship agreements due to unforeseen circumstances, when changes occur without warning or adequate notice, or without being accompanied by a plausible explanation and/or apology, suppliers quickly perceive unfair treatment by the buyer (Luo et al. 2015). Moreover, in global markets dominated by large buyers who often do not own production but are able to exert power through their prevailing marketing and brand position, suppliers may be forced to either institute excessive overtime working or increase work intensity (e.g. night and weekend work) to levels that exceed normal labour standards in order to meet order deadlines 
(Smith and Barrientos 2005; Locke et al. 2009; Lam 2012). In contrast, fair treatment is indicative of a buyer's trustworthiness and concern for the utility of the supplier (Wang et al. 2011). When a supplier feels that a buyer fully considers its concerns and informs it about major decisions, they feel comfortable and encouraged to communicate with that buyer (Huo et al. 2016). Interactional justice helps to curtail breaches of both contractual obligations and relational norms by reducing uncertainties and increasing mutual understanding between buyer and supplier (Luo et al. 2015). If buyers, for example, provide suppliers with adequate explanation and timely information about unexpected changes to order volume or delivery time (procedures), suppliers will be in a much better position to undertake the necessary adjustments and increase capacity (for example by hiring new workers) to accommodate these unforeseen modifications (Jiang 2009). It follows that suppliers are therefore likely to be less motivated to exhibit socially irresponsible opportunistic behaviours in order to protect their interests and to compensate for potential loss of contracts. Based on these arguments we propose the following:

Proposition 2c Buyers' interactional justice is positively related to suppliers' internal social performance.

We have disentangled how each dimension of justice can individually help to improve suppliers' internal social performance. The differential effects of justice dimensions on suppliers' internal social performance owes to the fact that each dimension relates to different aspects of the buyersupplier relationship. For the economic aspect, distributive justice can sustain suppliers' internal social performance by providing an equitable share of the value created in the relationship that otherwise would demotivate supplier from engaging in activities to improve their employees' welfare, increase investments in their working conditions and eradicate the use of child labour. Emphasising the structural aspect, procedural justice can sustain suppliers' internal social performance through ensuring a consistent application of relationship procedures and doing so in accordance with contract specifications that guide the buyer-supplier agreement. Emphasising the social aspect, interactional justice can improve suppliers' internal social performance by ensuring that adequate explanation and timely information regarding unexpected changes are provided so that suppliers have ample time to adapt. Prior research has highlighted that all three dimensions are essential and that a high level of one dimension will not compensate for a low level of another in buyer-supplier relationships (Wang et al. 2014; Luo et al. 2015; Narasimhan et al. 2013). Building on this view, we further argue that to realise a higher level of suppliers' internal social performance all dimensions of justice should be satisfied. It is our contention that the presence of only one or even two of the justice dimensions is not sufficient to yield the desired improvement in suppliers' internal social performance. For example, if buyers deliver a fair share of earnings to 
the supplier, but still demand unrealistic delivery times and inconsistent order volumes (procedural justice), and do not provide sufficient and timely information (interactional justice), the social conditions at the suppliers' operations are likely to remain relatively the same. Therefore, we propose that buyers should address all three dimensions simultaneously if they wish to improve suppliers' internal social performance:

Proposition 2d The higher the level of all three justice dimensions simultaneously (distributive, procedural and interactional), the higher will be suppliers' internal social performance.

\section{The moderating role of justice}

The implementation of SSTPs and SSCPs requires a level of cooperation that can be difficult to establish on the part of suppliers, particularly when more powerful buyers simultaneously demand constant price reductions, shorter lead times and maintenance/improvement of quality (Khara and Lund-Thomsen 2012; Lund-Thomsen and Lindgreen 2014). This indicates that suppliers' cooperation and engagement with buyers on sustainability issues through SSTPs and SSCPs is less likely to occur in the light of perceived unfairness in relationship outcomes, procedures and interactions. Therefore, in addition to the main direct effects of buyers' justice on suppliers' internal social performance, we further argue that a higher perception of buyers' justice can also enhance suppliers' internal social performance indirectly through increasing the effectiveness of SSTPs and SSCPs. In other words, under a higher perception of buyers' justice dimensions, the impact of SSTPs on supplier's internal social performance becomes significant, while the positive impact of SSCPs on suppliers' internal social performance becomes stronger. The impact of SSTPs on supplier's internal social performance becomes significant when supplier perceive buyer's justice is due to the fact when buyers share the costs of SSTPs with supplier (usually supplier bear the majority of costs of certification and auditing) that creates perception of justice by suppliers, which in turn leads to more compliance (Yu 2008; Normann et al. 2017; Huq et al. 2014).

Recent research has highlighted the potential role of informal mechanisms in contributing to the governance of sustainable supply chains (e.g. Jiang 2009; Alvarez et al. 2010). While the main research efforts in this context have identified trust and social norms as primary informal governance mechanisms, a growing literature on relational governance has featured the focal role of fairness in governing inter-organisational exchange relationships (e.g. Poppo and Zhou 2013; Luo 2007b). Procedural, distributive and interactional justice play a parallel role with existing structural and contract governance in motivating exchange partners to devote resources and communicate (Luo 2007b). Fairness has been shown to increase the effectiveness of formal 
governance mechanisms (Samaha et al. 2011; Hernandez-Espallardo and Arcas-Lario 2003). According to Wang et al. (2011), fairness can serve two effects in supply chain relationships: compliance and maintenance. In the compliance effect, fairness facilitates inter-organisational task fulfilment whilst curtailing costs. In the maintenance effect, fairness nurtures partners' satisfaction with collaboration and improves overall supply chain relationships.

\section{The moderating role of distributive justice}

A fair distribution of relationship outcomes is likely to strengthen the relationship between SSSC practices (SSTPs and SSCPs) and suppliers' internal social performance. SSTPs involve measuring and monitoring suppliers' performance which requires the exchange of information and inputs between buyer and supplier (Grosvold et al. 2014). Thus, information asymmetries between buyer and supplier can present an obstacle to implementing responsible practice (Ciliberti et al. 2009). Moreover, a supplier's ability to receive and interpret requirements from the focal company is considered one of the key aspects in successfully implementing social responsibility (Andersen and Skjoett-Larsen 2009). Distributive justice paves the way for mutual information sharing and knowledge transfer in the relationship (Liu et al. 2012). Fair sharing of relationship outcomes helps eliminate fears of exploitation and stimulates openness of communication between partners (Luo 2007b; Tyler and Bies 1990). Furthermore, when a relationship is built on equal distribution of gains and losses, both parties are more likely to be motivated and amenable to share valuable knowledge resources (Modi and Mabert 2007). Perception of equity of gains in the relationship, in turn, can reduce transaction and coordination costs as a partner would be inclined to exert less scrutiny and monitoring of efforts with its counterpart (Luo 2007a).

Stakeholder utility and perception of shared value have been identified as key requirements for successful collaboration in global supply chains (Soundararajan and Brown 2016). Initiating capability development and training programmes requires joint activity with suppliers (Klassen and Vereecke 2012). According to Wagner et al. (2011), a buyer's perception of supplier's outcome fairness increases its willingness to continue the relationship and to collaborate in the future. The benefits of distributive justice facilitate dynamic adjustment and flexibility in supply chain relationships (Griffith et al. 2006). Fairness has been shown to play a pivotal role in encouraging suppliers' participation in and compliance with joint programmes initiated by buyers (Gu and Wang 2011). Buyer-supplier collaboration on sustainability issues also requires the exchange of and investment in resources and technical skills (Klassen and Vereecke 2012). Enhanced distributive justice can facilitate mutual access to and the sharing of partners' resources (Luo 2007a). When partners in a relationship receive an appropriate reward for their contributions 
from the other party, they are more likely to become more confident in the fairness of future benefits and profit distribution, which increases further commitment and investments in the relationship (Kumar et al. 1995; Liu et al. 2012; Luo et al. 2015). SSCPs also require buyers and suppliers to exchange information and knowledge on new product development and process redesign that helps to guarantee health and safety for employees (Marshall et al. 2015; Klassen and Vereecke 2012). Higher perceptions of fair rewards encourage supply chain partners to exchange innovative ideas which promote the development of new products and improved processes (Shockley and Turner 2016). If suppliers feel they are fairly treated in terms of gains, they will invest and engage more in the buyers' efforts to develop new innovations (Duffy et al. 2013). Based on the above discussion we suggest the following:

Proposition 3a Distributive justice moderates the relationship between SSTPs and suppliers' internal social performance in such a fashion that the relationship becomes significant and positive when the supplier perceives a higher level of distributive justice.

Proposition 3b Distributive justice moderates the relationship between SSCPs and suppliers' internal social performance in such a fashion that the positive effect of SSCPs on suppliers' internal social performance is stronger when the supplier perceives a higher level of distributive justice.

\section{The moderating role of procedural justice}

Procedural justice represented by suppliers' perception of consistent, bias free, accurate, correctable and ethical procedures is expected to strengthen the link between SSSC practices (SSTPs and SSCPs) and suppliers' internal social performance. SSTPs involve setting targets, and measuring and monitoring performance which requires the exchange of information and data between buyer and supplier (Grosvold et al. 2014). As already noted, a supplier's ability to receive and interpret the requirements from the buyer is one of the key aspects of successfully implementing social responsibility (Andersen and Skjoett-Larsen 2009). Procedural justice improves effective communication and reinforces mutual understanding between partners (Farh et al. 1997). Reciprocation and communication may be further improved because this common perception encourages openness in interactions and curbs fears of exploitation (Luo 2005). Procedural justice can also improve partners' voluntary cooperation and knowledge sharing beyond their 'normal' contract responsibilities (Liu et al. 2012; Ling-yee 2010). This enhances governance structure, flexibility and functionality, which in turn offers a guiding framework under which participation can continue and advance (Luo 2008). Procedural justice improves relationship formalisation and the routinisation that guides daily exchanges between parties (Luo 2007a). A perception of procedural justice can therefore improve commitment through more 
active participation in joint decision making and through better compliance with relationship rules and improved partner unity (Allen and Meyer 1990). According to Klassen and Vereecke (2012), when supply chain partners have similar cultures and only a narrow gap of understanding, the complexity and time needed for monitoring social issues becomes less and reporting suppliers' social performance becomes more precise. Procedural justice improves mutual actions between organisations by bridging culture gaps and reducing uncertainty during cooperation (Luo 2005).

SSCPs that focus on initiating supplier capability development and training programmes require joint activities with suppliers and the exchange of knowledge on new product development and process redesign that helps to improve and consolidate health and safety for employees (Marshall et al. 2015). Parties in a relationship use procedural justice as a guide in their commitment level to joint activities when limited prior information is available on the trustworthiness of their counterparts and on the assurance of the final outcomes from the relationship (Luo 2008). Moreover, procedural justice fosters trading partners' commitment to joint efforts by increasing the belief and acceptance of shared goals and values (Brockner 2002; Johnson 1997). Procedural fairness can improve cooperation outcomes by increasing trust and reducing opportunism and conflicts between buyer and suppliers (Hofer et al. 2012; Luo 2008). Moreover, shared procedural justice can increase process efficiency and in turn reduce operating and administrative costs (Luo 2005). Fair procedures promote buyer-supplier learning of innovative ways to undertake new product and solutions development (Tjosvold et al. 2010). Buyer-supplier collaboration on sustainability issues also requires the allocation and exchange of resources and expertise (Klassen and Vereecke 2012). Procedural justice creates a flourishing and fertile setting for developing relationship-specific assets (i.e. individual skills, organisational practices, or technologies) within an exchange relationship (Luo 2005; Sapienza and Korsgaard 1996). This suggests that procedural justice contributes to enhancing cooperation by enabling more long-term risk and resource sharing (Luo 2008). Partners generally allocate their resource contributions and commitments to the relationship based on both contractual requirements and their own evaluation of justice (Luo 2005). When both partners perceive a high level of procedural justice however, they perceive that their interests are safeguarded through policies and accordingly they are more inclined to invest in and continue with the relationship (Liu et al. 2012; Huo et al. 2016). Moreover, parties are more likely to be willing to incur costs associated with adaptations to new/revised decisions in the relationship when they feel that the relationship is characterised by a high level of procedural justice because procedural justice provides an indication of assurance of long-term gains (Busenitz et al. 2004). Based on the above discussion we propose the following: 
Proposition 4a Procedural justice moderates the relationship between SSTPs and suppliers' internal social performance in such a fashion that the relationship becomes significant and positive when the supplier perceives a higher level of procedural justice.

Proposition 4b Procedural justice moderates the relationship between SSCPS and suppliers' internal social performance in such a fashion that the positive effect of SSCPS on suppliers' internal social performance is stronger when the supplier perceives a higher level of procedural justice.

\section{The moderating role of interactional justice}

We also expect, and hence propose, that the interactional justice of buyers - which is supported by their provision of explanation and information about decisions and exhibiting a heightened level of interpersonal treatment - will exert a positive moderating effect on the relationship between SSSC practices (SSTPs and SSCPs) and suppliers' internal social performance. In SSTPs, objectives are specified, performance is audited, progress is monitored, feedback is provided and rewards and punishments are administered to help to align suppliers' behaviour with buyers' criteria (Klassen and Vereecke 2012; Porteous et al. 2015). This process, therefore, requires the gathering and processing of information from buyers and suppliers (Grosvold et al. 2014). However, information asymmetries between buyer and supplier can present a major obstacle in socially responsible supply chains (Ciliberti et al. 2009). Increased interactional justice fosters information processing through improved open communication and heightened willingness to share information and air differences, allowing boundary spanners to draw inferences and assumptions about their organisations and environments by exchanging available information and then using that information to define and solve problems (Luo 2006b). In fact, it has been argued that when a weak partner in an asymmetrical relationship receives an explanation underlying the setting of a specific policy or rule from their counterpart, it will become more motivated to share additional information (Griffith et al. 2006). Interactional justice and fair treatment in interpersonal relations strengthens relational attachment through heightened communication, socialisation and knowledge sharing between organisations (Luo 2007a; 2006a). Moreover, a supplier's ability to receive and interpret the requirements of a buyer is, as mentioned previously, one of the key aspects of successfully implementing social responsibility (Andersen and Skjoett-Larsen 2009). Improved interactional justice helps generate standards of expected behaviour for social interactions and helps to create the cooperative climate (Luo 2006b). According to $\mathrm{Hu}$ et al. (2016) during the implementation of multinational firms' supply relationships, the respect shown by them during supplier auditing activities was critical in driving suppliers' cooperation. 
SSCPs require the exchange of, and investment in, resources and technical skills (Klassen and Vereecke 2012; Sancha et al. 2016). Exchange partners increase their willingness to commit to the relationship when they feel that they are treated with admiration and dignity by other partners (Beugré and Acar 2008). Effectively, both buyer and supplier are more likely to commit to the relationship when they both perceive a high level of informational justice (Liu et al 2012). Commitment enhances supply chain partners willingness to invest their time, effort and attention (Wang et al. 2014; Duffy et al. 2013). Moreover, through informational justice, both parties will provide valuable information that is important to the other, behaviour which can help reduce information asymmetry, decrease each party's perceived uncertainty about the other's behaviours, and promote specific investment in the relationship on the part of both parties (Trada and Goyal 2017; Huo et al. 2016; Crosno et al. 2013). SSCPs also involve initiating capability development and training programmes which require joint activities (Klassen and Vereecke 2012). Interactional justice improves teamwork and joint efforts which prompt coordination, understanding and learning and consequently can curb coordination expenses and expenses incurred through otherwise bureaucratic processes (Luo 2007a). Interactional justice signals the counterpart's trustworthiness and commitment to cooperation (Luo 2006b). When interactional justice is high, it is likely that the transacting parties develop greater trust (Wang et al. 2014), satisfaction (Ting 2011) and commitment towards one and other (Zaefarian et al. 2016). According to Narasimhan et al. (2013), interactional justice enables both buyer and supplier to exert less effort in achieving the relationship outcomes by resolving conflicts faster and through better assessment of needs in their collaboration. Based on the above discussion we suggest the following:

Proposition 5a Interactional justice moderates the relationship between SSTPs and suppliers' internal social performance in such a fashion that the relationship becomes significant and positive when the supplier perceives a higher level of interactional justice.

Proposition 5b Interactional justice moderates the relationship between SSCPS and suppliers' internal social performance in such a fashion that the positive effect of SSCPs on suppliers' internal social performance is stronger when the supplier perceives a higher level of interactional justice. 


\section{Discussion}

\section{Theoretical implications}

Sustainable supply chain management (SSCM) is an emerging field (Pagell and Shevchenko 2014; Walker et al. 2014) now receiving considerable attention, as is reflected in the large number of SSCM publications (Ansari and Kant 2017; Johnsen et al. 2017). Despite the significant progress that has been made in the last decade, SSCM research remains largely silent on how to create truly sustainable supply chains form the social sustainability perspective (Pagell and Shevchenko 2014). Whereas prior research has traditionally drawn on different theoretical perspectives (e.g. TCE and the RV) to suggest that buying firms should use conventional practices (SSTPs and SSCPs) to ensure suppliers' adherence to social expectations, we take a step forward and draw on organisational justice theory to introduce an alternative yet complementary approach to social sustainability. In particular, we provide theoretical insights into how buyers' justice (distributive, procedural and interactional justice) can directly and indirectly drive suppliers' internal social performance.

Our study adds a different and new dimension to the current scholarly conversations on how buying firms can promote improvements in working conditions and labour rights at their suppliers' workplace (e.g. Klassen and Vereecke 2012; Sancha et al. 2016; Huq et al. 2016). We do this by providing a fresh relational approach that we believe can tackle some of the major root causes of suppliers' social performance deficiencies. We have taken a nuanced view in our model to disentangle the individual and the interactive effects of distributive, procedural and interactional justice on suppliers' internal social performance, which has not been advanced before in this context. We highlighted that providing an equal share of the value created in the relationship by buyers can potentially mitigate against suppliers engaging in unethical activities in their internal workplace, such as eroding their employees' welfare, reducing investments in their working conditions and employing child labour. We also identified that ensuring a consistent application of relationship procedures (e.g. delivery times) that comply with contract specifications is expected to reduce the level of uncertainty suppliers face, which in turn can help to sustain their internal social performance. We also pointed out that when buyers provide reliable and timely information about unexpected changes (e.g. to order volumes), suppliers can more accurately and effectively plan, reschedule and control capacity in their factories using acceptable practices (e.g. hiring new employees) to meet these changes. Given these unique roles played by the three justice dimensions, we further suggested that they complement each other in driving suppliers' internal social performance. Specifically, we explained that not exhibiting all three 
dimensions may not yield the expected or desired level of improvement in suppliers' social conditions.

Our study also advances the current knowledge by providing an in-depth explanation of how distributive, procedural and interactional justice can underpin and enable the effective implementation of SSTPs and SSCPs by demonstrating the proposed moderating effects of all three justice dimensions on the relationship between SSSC practices and suppliers' internal social performance. Although some prior studies have provided an initial understanding of the role of buyers' justice in the implementation of SSSC management (Boyd et al. 2007; Theodorakopoulos et al. 2015), these studies provided only a limited view by focusing on procedural justice in the implementation process rather than buyers' overall justice in the relationship, and hence failed to capture the importance and unique role of each of the three prevalent justice dimensions in the implementation of SSTPs and SSCPs. We have therefore extended prior research by stipulating how justice returns, procedures and interactions can improve the implementation of SSTPs and SSCPs. We highlighted that when suppliers perceive the relationship being fair in terms of returns, perceive procedures to be consistent, and perceive the provision of timely information and proper justification for unpredictable changes, suppliers become more confident in the relationship future and more willing and motived to cooperate and commit to the implementation of SSTPs and SSCPs. Suppliers use relationship justice as a frame of reference to guide their level of commitment to social sustainability in the form of frequent sharing of knowledge and allocating sustainability-specific financial and human investments.

\section{Managerial implications}

Supply chain managers are constantly under pressure from different stakeholders to enhance the conditions under which their outsourced items are being produced. Managing the social issues of suppliers, particularly those located in remote areas, is a critical task. Our study provides a number of practical implications that can help supply chain managers to better understand and manage socially sustainable supply chains. First, both SSTPs and SSCPs are unlikely alone to be effective in driving suppliers to enhance the social conditions within their internal environment. Our synthesis of the previous research on SSCM indicates that in particular, SSTPs are less likely to influence suppliers to improve social sustainability performance. A successful implementation of SSTPs and SSCPs often requires a level of cooperation that can be difficult to establish, particularly on the part of suppliers. Supply chain managers need to establish the conditions that stimulate active participation and engagement of suppliers in their social responsibility programmes. 
Second, our work indicates that creating the perception of a fair relationship with suppliers appears to account for a change in suppliers' motivations and an increase in suppliers' commitment towards the SSSC initiatives established by buyers. That is to say, that a perception of overall distributive, procedural and interactional justice stimulates frequent communication and knowledge sharing, facilitates joint activities and can increase resource commitment within the relationship - all of which are key aspects supporting successful SSSC practices implementation. Therefore, supply chain managers need to ensure that distributive, procedural and interactional justice are established in parallel with SSTPs and SSCPs to effectively improve suppliers' internal social performance. For example, since the perception of distribution justice vary according to what and how inputs and outcomes are valued, managers can share information with suppliers to increase transparency and reduce suppliers concerns for unfair returns. Moreover, managers can ensure stable and consistent application of the procedures over time (at least over the short term) and most importantly across suppliers, and that equal opportunities exist to modify and correct these procedures at any stage of the relationship to develop a perception of procedural justice. Furthermore, holding regular relationship steering meetings, establishing integrated information system and interaction routines would be rich mechanisms for managers to share timely information and develop a mutual respect that are necessary to foster a perception of interactional justice.

Finally, our study indicates that the effect of justice goes beyond helping firms to recover from existing social performance transgressions, by directly constraining suppliers' possible engagement in social misconduct in the first place. Each dimensions of justice (distributive, procedural and interactional) serves a unique role in creating and sustaining the social conditions in suppliers' facilities. A fair distribution of relationship outcomes can reduce a supplier's intention to involve itself in unethical activities that it may otherwise feel are necessary due to the presence of perceived inequity. Moreover, a consistent application of fair relationship procedures can help to ensure stable supplier operations that in turn minimise the likelihood of poor practices such as the implementation of long and tiring shift work. Furthermore, a constant share of adequate and timely information will support suppliers in their efforts to take responsible actions, for example, to cope with unexpected demand fluctuations, rather than using unethical practices to respond to sudden increases in order size. These arguments infer that supply chain managers should invest in activities, practices and policies that promote the development of a perception of the three facets of justice when they deal with suppliers. Supply chain managers need to work regularly with suppliers through dedicated and ongoing interactions directed at aligning their understanding regarding relationship returns and procedures. 


\section{Future research directions}

This paper provides the foundation for several avenues of future research. First, although very few studies have examined the individual impact of SSTPs and SSCPs on suppliers' social performance, their joint effect has yet to be understood. In this paper we assume neither a substitution nor synergistic relationship between SSTPs and SSCPs. Sancha et al. (2016) recently revealed that these two sets of practices may be related in the sense that SSTPs may be antecedents to SSCPs. This might indicate that SSTPs and SSCPs are mutually exclusive and should not be implemented simultaneously. Wagner (2010) previously found a detrimental effect of implementing the indirect and direct supplier development activities simultaneously on suppliers' operational performance and capabilities improvement. Is this the case in the context of suppliers' social performance? A better understanding of the implications of the joint implementation of SSSC practices would help buying firms in their efforts to implement the most effective combination of SSSC practices to improve suppliers' social performance. Future research should therefore extend our work by considering and examining what, if any, interrelationships may exist between SSCPs and SSTPs.

The second avenue that we recommend is the empirical examination of our proposed conceptual framework within operating supply chains. Such empirical examination can confirm or otherwise whether buyers' justice serves as a substitute for and/or a complement for SSSC practices in driving the social improvements of suppliers. Moreover, future testing of our framework would reveal the relative importance of the three dimensions of justice to suppliers' internal social performance, and to what extent that may differ in different supply chain contexts (e.g. industry or geographical location, amongst many others). Future research can also provide more insights by disentangling which dimension of justice is important in relation to which type of SSSC practice. Distributive justice, arguably, is likely to be more relevant and effective in increasing supplier's social performance in parallel with SSTPs, while procedural and interactional justices are likely to be more salient in conjunction with SSCPs. However this needs empirical verification.

A third salient research avenue is to extend our model and empirically examine whether the direct impact of buyers' justice on suppliers' internal social performance holds across different governance forms, for example formal versus relational. Further insights could be gained by using the logic of self-interest and group-value models (Lind and Tyler 1988) in the organisational justice literature to explore which justice dimension is more important in which model or governance domain. Specifically, based on the self-interest model, we might expect that in transactional governance, distributive justice is more important in driving suppliers' internal 
social performance. In contrast, based on the group-value model, arguably we would predict that in relational governance it is procedural and interactional justice which would be more salient. Moreover, future research investigations should include relationship contextual variables such as dependence structure and relationship age to refine our proposed relationships.

Fourth, in our theoretical development in this paper we have examined and proposed the role of overall relationship fairness, rather than specifically the perceived fairness of the implementation of SSSC practices (e.g. Boyd et al. 2007). The implementation of SSSC practices requires investments and resources by both parties and may yield returns. Another promising future research avenue, therefore, is to explore how suppliers react to perceived fairness or unfairness in the implementation process of SSSC practices. Specifically, future research could use longitudinal case studies to explore how the perception of fairness in SSTPs and SSCPs develops during the implementation and how it might affect the participation of relationship partners in these practices. For example, would the use initially of SSTPs lead to a perception of unfairness as it inevitably is likely to require more costs on the part of supplier (Huq et al. 2014), whilst the use initially of SSCPs would lead to a perception of fairness, and consequently increase supplier satisfaction and compliance with the overall implementation of SSCPs and SSTPs?

Fifth, valuable insights can be gained from examining our framework by collecting data from buyer-supplier dyads and including suppliers' workers' views in the analysis. More specifically, perceptions of justice can be sought from the suppliers' side, details about the implementation of SSSC practices can be obtained from the buyers' side, and suppliers' internal social performance can be captured from the suppliers' workers' perspective. Although the field of SSCM has recently made good progress in developing reliable measures of sustainability performance (in particular environmental) by using secondary data rather than relying on perceptions (Pagell and Shevchenko 2014), the perceptions of marginalized workers have been overlooked (e.g. social issues). Moreover, the difficulty in quantifying the social performance element of overall sustainability performance has been identified as one of the main reasons for its relative absence from SSCM research (Hutchins and Sutherland 2008). Future research could therefore use intraorganisational justice dimensions (i.e. distributive, procedural and interactional) to capture suppliers' internal social performance from the workers' perspective. We believe such an approach would provide a more comprehensive measure covering several critical social issues that may be present, or even prevalent, in suppliers' operations/premises, including the fairness of payment (distributive justice), the fairness of procedures that govern the distribution of outcomes (procedural justice), and perhaps most importantly the way workers are treated (interactional justice). This approach could also be effective in reducing potential bias (i.e. social desirability) 
that may arise directly from buyer or supplier top management reporting on this type of performance. Top management perception of what are acceptable working conditions may not match the views of other stakeholders (Pagell and Shevchenko 2014) such as suppliers' employees.

Finally, the high failure rate and the challenges associated with implementing SSSC practices should motivate scholars to study how to more effectively coordinate them to deliver on their promise of improving suppliers' social performance. We have identified justice dimensions as important relational factors that can potentially increase the effectiveness of the implementation of SSSC initiatives. Future research could explore other relational factors that drive the implementation of SSSC practices. An increasing amount of research has highlighted the critical role of social capital in enhancing a variety of aspects in supply chain relationships including information sharing ( $\mathrm{Li}$ et al. 2014), learning (Kohtamäki and Bourlakis 2012), resilience (Johnson et al. 2013), and in reducing opportunism (Wang et al. 2013; Lioliou and Zimmermann 2015). Arguably these are all essential for the successful implementation of SSSC practices. Therefore, future research could explore the moderating effect of social capital dimensions (i.e. relational, cognitive and structural) on the relationship between SSSC practices (SSTPs and SSCPs) and suppliers' internal social performance.

\section{Compliance with Ethical Standards}

Conflict of interest The authors declare that they have no conflict of interest.

Ethical Approval This article does not contain any studies with human participants or animals performed by any of the authors.

\section{References}

Adams, J. S. (1965). Inequity in social exchange. In L. Berkowitz (Eds.), Advances in Experimental Social Psychology, (Vol. 2, pp. 267-299). Academic Press, New York.

Ahi, P., \& Searcy, C. (2015). Measuring social issues in sustainable supply chains. Measuring Business Excellence, 19(1), 33-45.

Ahi, P., Jaber, M. Y., \& Searcy, C. (2016). A comprehensive multidimensional framework for assessing the performance of sustainable supply chains. Applied Mathematical Modelling, 40(23), 10153-10166.

Allen, N. J., \& Meyer, J. P. (1990). The measurement and antecedents of affective, continuance and normative commitment to the organization. Journal of Occupational and Organizational Psychology, 63(1), 1-18. 
Alvarez, G., Pilbeam, C., \& Wilding, R. (2010). Nestlé Nespresso AAA sustainable quality program: an investigation into the governance dynamics in a multi-stakeholder supply chain network. Supply Chain Management: An International Journal, 15 (2), 165-182.

Andersen, M., \& Skjoett-Larsen, T. (2009). Corporate social responsibility in global supply chains. Supply Chain Management: An International Journal, 14(2), 75-86.

Ansari, Z. N., \& Kant, R. (2017). A state-of-art literature review reflecting 15 years of focus on sustainable supply chain management. Journal of Cleaner Production, 142, 2524-2543.

Aquino, K. (1995). Relationships among pay inequity, perceptions of procedural justice, and organizational citizenship. Employee Responsibilities and Rights Journal, 8(1), 21-33.

Awaysheh, A., \& Klassen, R. D. (2010). The impact of supply chain structure on the use of supplier socially responsible practices. International Journal of Operations \& Production Management, 30(12), 1246-1268.

Barney, J. (1991). Firm resources and sustained competitive advantage. Journal of Management, 17(1), 99-120.

Barrientos, S. (2013). Corporate purchasing practices in global production networks: A socially contested terrain. Geoforum, 44, 44-51.

Beske-Janssen, P., Johnson, M. P., \& Schaltegger, S. (2015). 20 years of performance measurement in sustainable supply chain management-what has been achieved?. Supply Chain Management: An international Journal, 20(6), 664-680.

Beugré, C. D., \& Acar, W. (2008). Offshoring and cross-border interorganizational relationships: A justice model. Decision Sciences, 39(3), 445-468.

Blancero, D., \& Ellram, L. (1997). Strategic supplier partnering: A psychological contract perspective. International Journal of Physical Distribution \& Logistics Management, 27(9/10), 616-629.

Boyd, D. E., Spekman, R. E., Kamauff, J. W., \& Werhane, P. (2007). Corporate social responsibility in global supply chains: a procedural justice perspective. Long Range Planning, 40(3), 341-356.

Brock, C., Blut, M., Evanschitzky, H., \& Kenning, P. (2013). Satisfaction with complaint handling: a replication study on its determinants in a business-to-business context. International Journal of Research in Marketing, 30(3), 319-322.

Brockner, J. (2002). Making sense of procedural fairness: How high procedural fairness can reduce or heighten the influence of outcome favorability. Academy of Management Review, 27(1), 58-76. 
Brown, J. R., Cobb, A. T., \& Lusch, R. F. (2006). The roles played by interorganizational contracts and justice in marketing channel relationships. Journal of Business Research, 59(2), 166-175.

Brown, J. R., Dev, C. S., \& Lee, D. J. (2000). Managing marketing channel opportunism: the efficacy of alternative governance mechanisms. Journal of Marketing, 64(2), 51-65.

Brown, J. R., Lusch, R. F., \& Nicholson, C. Y. (1995). Power and relationship commitment: Their impact on marketing channel member performance. Journal of Retailing, 71(4), 363392.

Busenitz, L. W., Fiet, J. O., \& Moesel, D. D. (2004). Reconsidering the venture capitalists' "value added" proposition: An interorganizational learning perspective. Journal of Business Venturing, 19(6), 787-807.

Carter, C. R., \& Rogers, D. S. (2008). A framework of sustainable supply chain management: moving toward new theory. International Journal of Physical Distribution \& Logistics Management, 38(5), 360-387.

Ciliberti, F., de Groot, G., de Haan, J., \& Pontrandolfo, P. (2009). Codes to coordinate supply chains: SMEs' experiences with SA8000. Supply Chain Management: An International Journal, 14(2), 117-127.

Colquitt, J. A. (2001). On the dimensionality of organizational justice: a construct validation of a measure. Journal of Applied Psychology, 86 (3), 386-400.

Crane, A. (2013). Modern slavery as a management practice: Exploring the conditions and capabilities for human exploitation. Academy of Management Review, 38(1), 49-69.

Crosno, J. L., Manolis, C., \& Dahlstrom, R. (2013). Toward understanding passive opportunism in dedicated channel relationships. Marketing Letters, 24(4), 353-368.

Deutsch, M. (1975). Equity, equality, and need: What determines which value will be used as the basis of distributive justice? Journal of Social Issues, 31(3), 137-149.

Duffy, R., Fearne, A., Hornibrook, S., Hutchinson, K., \& Reid, A. (2013). Engaging suppliers in CRM: The role of justice in buyer-supplier relationships. International Journal of Information Management, 33(1), 20-27.

Dyer, J. H., \& Singh, H. (1998). The relational view: Cooperative strategy and sources of interorganizational competitive advantage. Academy of Management Review, 23(4), 660679.

Farh, J. L., Earley, P. C., \& Lin, S. C. (1997). Impetus for action: A cultural analysis of justice and organizational citizenship behavior in Chinese society. Administrative Science Quarterly, 42(3), 421-444. 
Fassin, Y. (2005). The reasons behind non-ethical behaviour in business and entrepreneurship. Journal of Business Ethics, 60(3), 265-279.

Fearne, A., Duffy, R., \& Hornibrook, S. (2005). Justice in UK supermarket buyer-supplier relationships: an empirical analysis. International Journal of Retail \& Distribution Management, 33(8), 570-582.

Folger, R., \& Cropanzano, R. (1998). Organizational Justice and Human Resource Management. Sage Publication, Thousand Oaks, CA.

Fortin, M., Cojuharenco, I., Patient, D., \& German, H. (2016). It is time for justice: How time changes what we know about justice judgments and justice effects. Journal of Organizational Behavior, 37(1), 30-56.

Gallear, D., Ghobadian, A., \& Chen, W. (2012). Corporate responsibility, supply chain partnership and performance: An empirical examination. International Journal of Production Economics, 140(1), 83-91.

Gao, J., \& Bansal, P. (2013). Instrumental and integrative logics in business sustainability. Journal of Business Ethics, 112(2), 241-255.

Gimenez, C., Sierra, V., \& Rodon, J. (2012). Sustainable operations: Their impact on the triple bottom line. International Journal of Production Economics, 140(1), 149-159.

Gold, S., Hahn, R., and Seuring, S. (2013). Sustainable supply chain management in 'base of the pyramid' food projects - a path to triple bottom line approaches for multinationals?. International Business Review, 22(5), 784-799.

Greenberg, J. (1982). Approaching equity and avoiding inequity in groups and organizations. In J. Greenberg \& R. L. Cohen (Eds.), Equity and Justice in Social Behavior, (pp. 389-435), Academic Press, New York.

Greenhalgh, T., \& Peacock, R. (2005). Effectiveness and efficiency of search methods in systematic reviews of complex evidence: audit of primary sources. British Medical Journal, 331(7524), 1064-1065.

Griffith, D. A., Harvey, M. G., \& Lusch, R. F. (2006). Social exchange in supply chain relationships: The resulting benefits of procedural and distributive justice. Journal of Operations Management, 24(2), 85-98.

Grosvold, J., U. Hoejmose, S., \& K. Roehrich, J. (2014). Squaring the circle: Management, measurement and performance of sustainability in supply chains. Supply Chain Management: An International Journal, 19(3), 292-305.

Gu, F. F., \& Wang, D. T. (2011). The role of program fairness in asymmetrical channel relationships. Industrial Marketing Management, 40(8), 1368-1376. 
Gualandris, J., \& Kalchschmidt, M. (2016). Developing environmental and social performance: the role of suppliers' sustainability and buyer-supplier trust. International Journal of Production Research, 54(8), 2470-2486.

Gunasekaran, A., Patel, C., \& McGaughey, R. E. (2004). A framework for supply chain performance measurement. International journal of production economics, 87(3), 333-347.

Hemmert, M., Kim, D., Kim, J., \& Cho, B. (2016). Building the supplier's trust: Role of institutional forces and buyer firm practices. International Journal of Production Economics. 180, 25-37.

Henke, J. W, Jr, Parameswaran, R., \& Pisharodi, R. M. (2008). Manufacturer price reduction pressure and supplier relations. Journal of Business \& Industrial Marketing, 23(5), 287300.

Hernández-Espallardo, M., \& Arcas-Lario, N. (2003). Unilateral control and the moderating effects of fairness on the target's performance in asymmetric channel partnerships. European Journal of Marketing, 37(11/12), 1685-1702.

Hofer, A. R., Knemeyer, A. M., \& Murphy, P. R. (2012). The roles of procedural and distributive justice in logistics outsourcing relationships. Journal of Business Logistics, 33(3), 196-209.

Hollos, D., Blome, C., \& Foerstl, K. (2012). Does sustainable supplier co-operation affect performance? Examining implications for the triple bottom line. International Journal of Production Research, 50(11), 2968-2986.

Homans, G. (1961). Social Behaviour: Its Elementary Forms. Routledge \& Kegan Paul, London.

Hoppner, J., A. Griffith, D., \& Yeo, C. (2014). The intertwined relationships of power, justice and dependence. European Journal of Marketing, 48(9/10), 1690-1708.

Huo, B., Wang, Z., \& Tian, Y. (2016). The impact of justice on collaborative and opportunistic behaviors in supply chain relationships. International Journal of Production Economics, $177,12-23$.

Huq, F. A., Chowdhury, I. N., \& Klassen, R. D. (2016). Social management capabilities of multinational buying firms and their emerging market suppliers: An exploratory study of the clothing industry. Journal of Operations Management, 46, 19-37.

Huq, F. A., Stevenson, M., \& Zorzini, M. (2014). Social sustainability in developing country suppliers: An exploratory study in the ready made garments industry of Bangladesh, International Journal of Operations \& Production Management, 34 (5), 610-638.

Hutchins, M. J., \& Sutherland, J. W. (2008). An exploration of measures of social sustainability and their application to supply chain decisions. Journal of Cleaner Production, 16(15), 1688-1698. 
Jambulingam, T., Kathuria, R., \& Nevin, J. R. (2011). Fairness-trust-loyalty relationship under varying conditions of supplier-buyer interdependence. Journal of Marketing Theory and Practice, 19(1), 39-56.

Jiang, B. (2009). The effects of interorganizational governance on supplier's compliance with SCC: An empirical examination of compliant and non-compliant suppliers. Journal of Operations Management, 27(4), 267-280.

Johnsen, T. E., Miemczyk, J., \& Howard, M. (2017). A systematic literature review of sustainable purchasing and supply research: Theoretical perspectives and opportunities for IMP-based research. Industrial Marketing Management, 61, 130-143.

Johnson, J. P. (1997). Procedural justice perceptions among international joint venture managers. In P. W. Beamish, \& J. P Killing (Eds.), Cooperative strategies: North American perspectives, (pp. 197-226). New Lexington Press, San Francisco.

Johnson, J. T. (2006). The role of explicit contracts and cooperative norms on fairness in buyerseller relationships. Academy of Marketing Studies Journal, 10(2), 1-8.

Johnson, N., Elliott, D., \& Drake, P. (2013). Exploring the role of social capital in facilitating supply chain resilience. Supply Chain Management: An International Journal, 18(3), 324336.

Joo, S.-J., Min, H., Kwon, I.-W. G., \& Kwon, H. (2010). Comparative Efficiencies of Specialty Coffee Retailers from the Perspectives of Socially Responsible Global Sourcing. International Journal of Logistics Management, 21(3), 490-509.

Kashyap, V., Manolis, C., \& Brashear, T. G. (2008). A measure of distributive justice in distribution channels: Scale development and validation. Journal of Marketing Channels, 15(4), 253-279.

Kaynak, R., Sert, T., Sert, G., \& Akyuz, B. (2015). Supply chain unethical behaviors and continuity of relationship: Using the PLS approach for testing moderation effects of interorganizational justice. International Journal of Production Economics, 162, 83-91.

Khara, N., \& Lund-Thomsen, P. (2012). Value chain restructuring, work organization and labour outcomes in football manufacturing in India. Competition \& Change, 16(4), 261-280.

Klassen, R. D., \& Vereecke, A. (2012). Social issues in supply chains: Capabilities link responsibility, risk (opportunity), and performance. International Journal of Production Economics, 140 (1), 103-115.

Kohtamäki, M., \& Bourlakis, M. (2012). Antecedents of relationship learning in supplier partnerships from the perspective of an industrial customer: the direct effects model. Journal of Business \& Industrial Marketing, 27(4), 299-310. 
Kumar, N., Scheer, L. K., \& Steenkamp, J. B. E. (1995). The effects of supplier fairness on vulnerable resellers. Journal of Marketing Research. 32(1), 54-65.

Lam, M. L. L. (2012). An Alternative Paradigm of Managing Sustainability in the Global Supply Chain. International Journal of Social Ecology and Sustainable Development (IJSESD), $3(4), 1-12$.

Lee, S. Y. (2015). The effects of green supply chain management on the supplier's performance through social capital accumulation. Supply Chain Management: An International Journal, 20(1), 42-55.

Leire, C., \& Mont, O. (2010). The implementation of socially responsible purchasing. Corporate Social Responsibility and Environmental Management, 17(1), 27-39.

Leventhal, G. S. (1980). What should be done with equity theory? New approaches to the study of fairness in social relationships. In K. Gergen, M. Greenberg, \& R. Willis (Eds.), Social exchange: Advances in Theory and Research, (pp. 27-55). Plenum Press, New York.

Li, A., \& Cropanzano, R. (2009). Fairness at the group level: Justice climate and intraunit justice climate. Journal of Management, 35(3), 564-599.

Li, Y., Ye, F., \& Sheu, C. (2014). Social capital, information sharing and performance: Evidence from China. International Journal of Operations \& Production Management, 34(11), 14401462 .

Lim, S. J., \& Phillips, J. (2008). Embedding CSR values: The global footwear industry's evolving governance structure. Journal of Business Ethics, 81(1), 143-156.

Lind, E. A., \& Tyler, T. R. (1988). The Social Psychology of Procedural Justice. Plenum Press. Spring Street, New Work.

Ling-yee, L. (2010). Encouraging extra-role behavior in a channel context: The role of economic, social-, and justice-based sharedness mechanisms. Industrial Marketing Management, 39(2), 195-201.

Lioliou, E., \& Zimmermann, A. (2015). Vendor opportunism in IT outsourcing: a TCE and social capital perspective. Journal of Information Technology, 30(4), 307-324.

Liu, A., Leach, M., \& Chugh, R. (2015). A sales process framework to regain B2B customers. Journal of Business \& Industrial Marketing, 30(8), 906-914.

Liu, Y., Huang, Y., Luo, Y., \& Zhao, Y. (2012). How does justice matter in achieving buyersupplier relationship performance?. Journal of Operations Management, 30(5), 355-367.

Liu, Y., Luo, Y., Huang, Y., \& Yang, Q. (2017). A diagnostic model of private control and collective control in buyer-supplier relationships. Industrial Marketing Management, 63, 116-128. 
Locke, R., Amengual, M., \& Mangla, A. (2009). Virtue out of necessity? Compliance, commitment, and the improvement of labor conditions in global supply chains. Politics \& Society, 37(3), 319-351.

Lund-Thomsen, P. (2008). The global sourcing and codes of conduct debate: five myths and five recommendations. Development and Change, 39(6), 1005-1018.

Lund-Thomsen, P., \& Lindgreen, A. (2014). Corporate social responsibility in global value chains: Where are we now and where are we going? Journal of Business Ethics, 123 (1), $11-22$.

Luo, Y. (2005). How important are shared perceptions of procedural justice in cooperative alliances? Academy of Management Journal, 48(4), 695-709.

Luo, Y. (2006a). Opportunism in Inter-firm Exchanges in Emerging Markets. Management and Organization Review, 2(1), 121-147.

Luo, Y. (2006b). Toward the micro and macro-level consequences of interactional justice in cross-cultural joint ventures. Human Relations, 59(8), 1019-1047.

Luo, Y. (2007a). The independent and interactive roles of procedural, distributive, and interactional justice in strategic alliances. Academy of Management Journal, 50(3), 644664.

Luo, Y. (2007b). An integrated anti-opportunism system in international exchange. Journal of International Business Studies, 38(6), 855-877.

Luo, Y. (2008). Procedural fairness and interfirm cooperation in strategic alliances. Strategic Management Journal, 29(1), 27-46.

Luo, Y., Liu, Y., Yang, Q., Maksimov, V., \& Hou, J. (2015). Improving performance and reducing cost in buyer-supplier relationships: The role of justice in curtailing opportunism. Journal of Business Research, 68(3), 607-615.

Mamic, I. (2005). Managing global supply chain: The sports footwear, apparel and retail sectors. Journal of Business Ethics, 59 (1-2), 81-100.

Marshall, D., McCarthy, L., Claudy, M., \& McGrath, P. (2016). Piggy in the Middle: How Direct Customer Power Affects First-Tier Suppliers' Adoption of Socially Responsible Procurement Practices and Performance. Journal of Business Ethics, 1-22.

Marshall, D., McCarthy, L., Heavey, C., \& McGrath, P. (2015a). Environmental and social supply chain management sustainability practices: Construct development and measurement. Production Planning \& Control, 26(8), 673-690.

Modi, S. B., \& Mabert, V. A. (2007). Supplier development: Improving supplier performance through knowledge transfer. Journal of Operations Management, 25(1), 42-64. 
Montabon, F., Pagell, M., \& Wu, Z. (2016). Making sustainability sustainable. Journal of Supply Chain Management, 52(2), 11-27.

Narasimhan, R., Narayanan, S., \& Srinivasan, R. (2013). An investigation of justice in supply chain relationships and their performance impact. Journal of Operations Management, 31(5), 236-247.

Pagell, M., \& Shevchenko, A. (2014). Why research in sustainable supply chain management should have no future. Journal of Supply Chain Management, 50(1), 44-55.

Patterson, P. G., Johnson, L. W., \& Spreng, R. A. (1996). Modeling the determinants of customer satisfaction for business-to-business professional services. Journal of the Academy of Marketing Science, 25(1), 4-17.

Perez-Aleman, P., and Sandilands, M. (2008). Building value at the top and the bottom of the global supply chain: MNC-NGO partnerships. California Management Review, 51(1), 2449.

Poppo, L., \& Zhou, K. Z. (2014). Managing contracts for fairness in buyer-supplier exchanges. Strategic Management Journal, 35(10), 1508-1527.

Porteous, A. H., Rammohan, S. V., \& Lee, H. L. (2015). Carrots or sticks? Improving social and environmental compliance at suppliers through incentives and penalties. Production and Operations Management, 24(9), 1402-1413.

Praxmarer-Carus, S., Sucky, E., \& Durst, S. M. (2013). The relationship between the perceived shares of costs and earnings in supplier development programs and supplier satisfaction. Industrial Marketing Management, 42(2), 202-210.

Pullman, M. E., Maloni, M. J., \& Carter, C. R. (2009). Food for thought: social versus environmental sustainability practices and performance outcomes. Journal of Supply Chain Management, 45(4), 38-54.

Rodríguez, J. A., Giménez Thomsen, C., Arenas, D., \& Pagell, M. (2016). NGOs’ Initiatives to Enhance Social Sustainability in the Supply Chain: Poverty Alleviation through Supplier Development Programs. Journal of Supply Chain Management, 52(3), 83-108.

Roth, A.V., Tsay, A.A., Pullman, M.E., \& Gray, J.V. (2008). Unraveling the food supply chain: strategic insights from China and the 2007 recalls. Journal of Supply Chain Management, 44(1), 22-39.

Samaha, S. A., Palmatier, R. W., \& Dant, R. P. (2011). Poisoning relationships: Perceived unfairness in channels of distribution. Journal of Marketing, 75(3), 99-117

Sancha, C., Gimenez, C., \& Sierra, V. (2016). Achieving a socially responsible supply chain through assessment and collaboration. Journal of Cleaner Production, 112(3), 1934-1947. 
Sancha, C., Gimenez, C., Sierra, V., \& Kazeminia, A. (2015). Does implementing social supplier development practices pay off? Supply Chain Management: An International Journal, 20(4), 389-403.

Sapienza, H. J., \& Korsgaard, M. A. (1996). Procedural justice in entrepreneur-investor relations. Academy of Management Journal, 39(3), 544-574.

Scheer, L. K., Kumar, N., \& Steenkamp, J. B. E. (2003). Reactions to perceived inequity in US and Dutch interorganizational relationships. Academy of Management Journal, 46(3), 303316.

Schleper, M. C., Blome, C., \& Wuttke, D. A. (2017). The dark side of buyer power: Supplier exploitation and the role of ethical climates. Journal of Business Ethics, 140(1), 97-114.

Seuring, S., \& Müller, M. (2008). From a literature review to a conceptual framework for sustainable supply chain management. Journal of Cleaner Production, 16(15), 1699-1710.

Shockley, J., \& Turner, T. (2016). A relational performance model for developing innovation and long-term orientation in retail franchise organizations. Journal of Retailing and Consumer Services, 32, 175-188.

Skarlicki, D. P., \& Folger, R. (1997). Retaliation in the workplace: The roles of distributive, procedural, and interactional justice. Journal of Applied Psychology, 82(3), 434-443.

Smith, S., \& Barrientos, S. (2005). Fair trade and ethical trade: are there moves towards convergence?. Sustainable Development, 13(3), 190-198.

Soundararajan, V., \& Brown, J. A. (2016). Voluntary governance mechanisms in global supply chains: Beyond CSR to a stakeholder utility perspective. Journal of Business Ethics, 134(1), 83-102.

Spekman , R. E., \& Davis, E. W. (2004). Risky business: expanding the discussion on risk and the extended enterprise. International Journal of Physical Distribution \& Logistics Management, 34(5), 414-433.

Suh, S. (2005). Fairness and relationship quality perceived by local suppliers: In search of critical success factors for international retailers. Journal of Global Marketing, 18(1-2), 5-19.

Tencati, A., Russo, A., \& Quaglia,V. (2008). Unintended consequences of CSR: Protectionism and collateral damage in global supply chains: The case of Vietnam. Corporate Governance, 8(4), 518-531.

Theodorakopoulos, N., Ram, M., \& Kakabadse, N. (2015). Procedural Justice in Procurement Management and Inclusive Interorganizational Relations: An Institutional Perspective. British Journal of Management, 26(2), 237-254.

Ting, S. C. (2011).The role of justice in determining relationship quality. Journal of Relationship Marketing, 10(2), 57-75. 
Tjosvold, D., Wong, A. S., \& Wan, P. M. (2010). Conflict management for justice, innovation, and strategic advantage in organizational relationships. Journal of Applied Social Psychology, 40(3), 636-665.

Touboulic, A., \& Walker, H. (2015). Love me, love me not: a nuanced view on collaboration in sustainable supply chains. Journal of Purchasing and Supply Management, 21(3), 178-191.

Trada, S., \& Goyal, V. (2017). The dual effects of perceived unfairness on opportunism in channel relationships. Industrial Marketing Management, 64, 135-146.

Tranfield D., Denyer D., \& Smart P. (2003). Towards a Methodology for Developing EvidenceInformed Management Knowledge by Means of Systematic Review. British Journal of Management, 14(3), 207-222.

Tyler, T., \& Bies, R. J. (1990). Beyond formal procedures: The interpersonal context of procedural justice. In J. Carroll (Eds.), Applied Social Psychology and Organizational Settings (pp. 77-98). Erlbaum, Hillsdale, NJ.

Vurro, C., Russo, A., \& Perrini, F. (2009). Shaping sustainable value chains: Network determinants of supply chain governance models. Journal of Business Ethics, 90(4), 607621.

Wagner, S. M. (2010). Indirect and direct supplier development: Performance implications of individual and combined effects. IEEE Transactions on Engineering Management, 57(4), 536-546.

Wagner, S. M., Coley, L. S., \& Lindemann, E. (2011). Effects of suppliers' reputation on the future of buyer-supplier relationships: the mediating roles of outcome fairness and trust. Journal of Supply Chain Management, 47(2), 29-48.

Walker, H. L., Seuring, S., Sarkis, J., \& Klassen, R. (2014). Sustainable operations management: recent trends and future directions [Editorial]. International Journal of Operations and Production Management, 34(5).

Wang, Q., Craighead, C. W., \& Li, J. J. (2014). Justice served: Mitigating damaged trust stemming from supply chain disruptions. Journal of Operations Management, 32(6), 374386.

Wang, Q., Li, J. J., Ross, W. T., \& Craighead, C. W. (2013). The interplay of drivers and deterrents of opportunism in buyer-supplier relationships. Journal of the Academy of Marketing Science, 41(1), 111-131.

Webster, J., \& Watson, R. T. (2002). Analyzing the past to prepare for the future: Writing a literature review. MIS quarterly, 26(5), xiii-xxiii. 
Wiengarten, F., \& Longoni, A. (2018). How does uncertainty affect workplace accidents? Exploring the role of information sharing in manufacturing networks. International Journal of Operations \& Production Management, 38(1), 295-310.

Williamson, O.E. (1975). Markets and Hierarchies: Analysis and Antitrust Implications, Free Press, New York.

Yanamandram, V., \& White, L. (2010). An empirical analysis of the retention of dissatisfied business services customers using structural equation modelling. Australasian Marketing Journal, 18(4), 222-232.

Yawar, S. A., \& Seuring, S. (2017). Management of social issues in supply chains: a literature review exploring social issues, actions and performance outcomes. Journal of Business Ethics, 141(3), 621-643.

Yilmaz, C., Sezen, B., \& Kabadayı, E. T. (2004). Supplier fairness as a mediating factor in the supplier performance-reseller satisfaction relationship. Journal of Business Research, 57(8), 854-863.

Yu, X. (2008). Impacts of Corporate Code of Conduct on Labor Standards: A Case Study of Reebok's Athletic Footwear Supplier Factory in China. Journal of Business Ethics, 81(3), 513-529.

Zaefarian, G., Najafi-Tavani, Z., Henneberg, S. C., \& Naudé, P. (2016). Do supplier perceptions of buyer fairness lead to supplier sales growth?. Industrial Marketing Management. 53, $160-171$.

Zorzini, M., Hendry, L. C., Huq, F. A., \& Stevenson, M. (2015). Socially responsible sourcing: reviewing the literature and its use of theory. International Journal of Operations \& Production Management, 35(1), 60-109. 
Table (1): The transactional and collaboration governance approaches

\begin{tabular}{|l|l|l|}
\hline \multicolumn{1}{|c|}{ Characteristics } & \multicolumn{1}{|c|}{ Transactional approach } & \multicolumn{1}{|c|}{ Collaboration approach } \\
\hline Main driver & Legitimacy & $\begin{array}{l}\text { Legitimacy and possible } \\
\text { competitive advantage (e.g. social } \\
\text { innovation) }\end{array}$ \\
\hline Timeframe & Short-term & Long-term \\
\hline Theoretical basis & Transaction Cost Economics (TCE) & Relational View (RV) \\
\hline Main assumptions & $\begin{array}{l}\text { Supplier performance are driven by } \\
\text { heavy monitoring and auditing }\end{array}$ & $\begin{array}{l}\text { Supplier performance are driven by } \\
\text { close collaboration and capability } \\
\text { building }\end{array}$ \\
\hline Main proposed mechanisms & $\begin{array}{l}\text { Monitoring; auditing; code of } \\
\text { conduct; third-party certification } \\
\text { and; contracts. }\end{array}$ & $\begin{array}{l}\text { Supplier development; resource } \\
\text { sharing (financial and human) and; } \\
\text { knowledge sharing }\end{array}$ \\
\hline Limitations & $\begin{array}{l}\text { Lack of suppliers' involvement in } \\
\text { setting sustainability goals; lack of } \\
\text { sharing the implementation costs; } \\
\text { neglecting suppliers' social and } \\
\text { cultural contexts. }\end{array}$ & $\begin{array}{l}\text { Applicable to selected suppliers; } \\
\text { long time needed to develop, } \\
\text { implement and achieve the } \\
\text { expected outcomes and; high } \\
\text { implementation costs. }\end{array}$ \\
\hline Direction of communication & $\begin{array}{l}\text { Often one-way communication } \\
\text { (Top-down approach) }\end{array}$ & Two-way communication \\
\hline Involved party (s) & Buyer; Supplier; third-party auditor & $\begin{array}{l}\text { Buyer; Supplier; NGOs and; civil } \\
\text { society }\end{array}$ \\
\hline
\end{tabular}


Table (2): An analysis of empirical research that examined the role and outcomes of justice in supply chain relationships

\begin{tabular}{|c|c|c|c|c|c|c|c|c|c|c|}
\hline \multirow{2}{*}{ Author(s) } & \multicolumn{4}{|c|}{$\begin{array}{c}\text { Justice } \\
\text { dimensions }\end{array}$} & \multirow{2}{*}{$\begin{array}{c}\text { Type of supply } \\
\text { chain } \\
\text { relationship }\end{array}$} & \multirow{2}{*}{$\begin{array}{l}\text { The perceiver of } \\
\text { justice }\end{array}$} & \multirow{2}{*}{ Method } & \multicolumn{2}{|c|}{ Context } & \multirow{2}{*}{ Relevant findings } \\
\hline & $\ddot{\theta}$ & 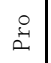 & $\stackrel{.}{.}$ & $\stackrel{\dot{Q}}{\underline{Q}}$ & & & & Industry & Country & \\
\hline Kumar et al. (1995) & $\checkmark$ & $\checkmark$ & & & $\begin{array}{l}\text { Manufacturer- } \\
\text { dealer }\end{array}$ & Dealer & Survey & Automobile & $\begin{array}{l}\text { Across } \\
\text { countries }\end{array}$ & $\begin{array}{l}\text { Higher perception of distributive and procedural fairness enhances relationship quality. However, distributive } \\
\text { justice becomes more important in determining relationship quality as the outcomes increase, while procedural } \\
\text { justice becomes more important as environment uncertainty increases. }\end{array}$ \\
\hline Patterson et al. (1996) & $\checkmark$ & & & & Buyer-supplier & Buyer & Survey & \begin{tabular}{c|c|} 
Management \\
consultant services
\end{tabular} & $\begin{array}{c}\text { Not } \\
\text { specified }\end{array}$ & $\begin{array}{l}\text { Client's (buyer) perception of outcome fairness of the service provider (supplier) is positively related to } \\
\text { satisfaction, which subsequently increases the client's repurchase intention. }\end{array}$ \\
\hline Scheer et al. (2003) & $\checkmark$ & & & & $\begin{array}{l}\text { Manufacturer- } \\
\text { dealer }\end{array}$ & Dealer & Survey & Automobile & $\begin{array}{l}\text { Across } \\
\text { countries }\end{array}$ & $\begin{array}{l}\text { Dutch and US dealers react negatively to negative inequity by exhibiting increased hostility, lower trust and lower } \\
\text { relationship continuity. When they experience positive inequity, Dutch dealers react negatively by showing lower } \\
\text { trust and relationship continuity and increasing guilty, whereas US dealers express no reaction. }\end{array}$ \\
\hline Yilmaz et al. (2004) & $\checkmark$ & $\checkmark$ & & & $\begin{array}{c}\text { Manufacturer- } \\
\text { dealer }\end{array}$ & Dealer & Survey & $\begin{array}{c}\text { Doors and window } \\
\text { systems }\end{array}$ & Turkey & $\begin{array}{l}\text { Manufacturers' financial and sales performance and operational support are shown to enhance the perception of } \\
\text { both distributive and procedural fairness, while delivery performance enhances the perception of procedural } \\
\text { fairness, which in turn increases dealer's satisfaction. }\end{array}$ \\
\hline Suh (2005) & $\checkmark$ & $\checkmark$ & & & Supplier-retailer & Supplier & Survey & Retail & South Korea & $\begin{array}{l}\text { Procedural justice fosters the relationship by curbing conflict and increasing trust and commitment. Distributive } \\
\text { justice enhances relationship quality by reducing conflict and increasing commitment. }\end{array}$ \\
\hline Brown et al. (2006) & $\checkmark$ & $\checkmark$ & & & $\begin{array}{l}\text { Supplier- } \\
\text { wholesaler }\end{array}$ & Wholesaler & Survey & Multiple industries & US & $\begin{array}{l}\text { The perceptions of supplier's distributive and procedural justice increase wholesaler's satisfaction, however, for } \\
\text { procedural justice only under a high level of distributive justice. Both distributive and procedural justices limit the } \\
\text { conflict between partners. }\end{array}$ \\
\hline Griffith et al. (2006) & $\checkmark$ & $\checkmark$ & & & $\begin{array}{l}\text { Manufacturer- } \\
\text { distributor }\end{array}$ & Distributor & Survey & Multiple industries & US & $\begin{array}{l}\text { Perception of procedural and distributive justice increase partner's performance through enhanced its attitude of } \\
\text { long-term orientation and behaviour responses (i.e. flexibility and information sharing). }\end{array}$ \\
\hline Ling-yee (2010) & & $\checkmark$ & & & $\begin{array}{l}\text { Manufacturer- } \\
\text { agent }\end{array}$ & Manufacturer & Survey & Electronics & China & $\begin{array}{l}\text { Perceived procedural justice enhances agent's extra role behaviours (voluntary cooperation and knowledge } \\
\text { sharing), which in turn improves relationship performance. }\end{array}$ \\
\hline $\begin{array}{l}\text { Yanamandram and } \\
\text { White (2010) }\end{array}$ & $\checkmark$ & $\checkmark$ & $\checkmark$ & & Buyer-supplier & Buyer & Survey & Business services & $\begin{array}{c}\text { Not } \\
\text { specified }\end{array}$ & $\begin{array}{l}\text { Distributive, procedural and interactional justices are positively related to the buyer satisfaction with complaint } \\
\text { handling in a B2B service context, which in turn increases repurchase intention. }\end{array}$ \\
\hline $\begin{array}{l}\text { Jambulingam et al. } \\
\quad(2011)\end{array}$ & $\checkmark$ & $\checkmark$ & & & $\begin{array}{l}\text { Wholesaler- } \\
\text { retailer }\end{array}$ & Retailer & Survey & Pharmaceutical & US & $\begin{array}{l}\text { Only under the condition of symmetric independence, trust completely mediates the relationship between fairness } \\
\text { and loyalty. However, under the conditions of perceived independence or asymmetric buyer dependence, } \\
\text { procedural and distributive fairness directly increase loyalty between supply chain partners. }\end{array}$ \\
\hline Samaha et al. (2011) & $\checkmark$ & & & & Seller-reseller & Reseller & Survey & Multiple industries & $\begin{array}{c}\text { Not } \\
\text { specified }\end{array}$ & $\begin{array}{l}\text { Perceived unfairness reduces reseller's cooperation and flexibility and magnifies the negative effects of conflict } \\
\text { and opportunism on cooperation and flexibility. Perceived unfairness erodes the effectiveness of using contracts in } \\
\text { governing the relationship. }\end{array}$ \\
\hline Wagner et al. (2011) & $\checkmark$ & & & & Buyer-supplier & Buyer & Survey & Multiple industries & $\begin{array}{l}\text { Across } \\
\text { countries }\end{array}$ & $\begin{array}{l}\text { Buyer perception of supplier's outcome fairness during project collaboration increases the buyer tendency to } \\
\text { continue the relationship and to collaborate in future. }\end{array}$ \\
\hline Hofer et al. (2012) & $\checkmark$ & $\checkmark$ & & & Buyer-supplier & Buyer & Survey & Not specified & Brazil & $\begin{array}{l}\text { Distributive and procedural justices increase buyer's trust and long-term orientation towards the relationship, } \\
\text { boosting cooperation, which enables buyer to pursue operational improvements. }\end{array}$ \\
\hline Liu et al. (2012) & $\checkmark$ & $\checkmark$ & $\checkmark$ & $\checkmark$ & $\begin{array}{l}\text { Manufacturer- } \\
\text { distributor }\end{array}$ & Dyads & Survey & Appliance & China & $\begin{array}{l}\text { High level of mutually perceived justice (i.e. distributive, procedural, interactional and informational) by both } \\
\text { parties lead to increased relationship performance through induced commitment between parties, enhanced } \\
\text { knowledge sharing and encouraged investment in the relationship. }\end{array}$ \\
\hline
\end{tabular}




\begin{tabular}{|c|c|c|c|c|c|c|c|c|c|c|}
\hline Brock et al. (2013) & $\checkmark$ & 8 & 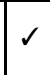 & & Buyer-supplier & Buyer & Survey & Construction & $\begin{array}{c}\text { Not } \\
\text { specified }\end{array}$ & $\begin{array}{l}\text { Both distributive justice and procedural justice positively related to the satisfaction with complaint handling of a } \\
\text { service failure in the context of B2B. }\end{array}$ \\
\hline Crosno et al. (2013) & $\checkmark$ & 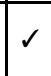 & 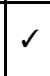 & & Supplier-retailer & Retailer & Survey & $\begin{array}{l}\text { Consumer } \\
\text { electronics }\end{array}$ & Norway & $\begin{array}{l}\text { Only interactional justice alleviates the impact of assets specific investment on passive opportunism in the } \\
\text { relationship. }\end{array}$ \\
\hline $\begin{array}{l}\text { Narasimhan et al. } \\
\text { (2013) }\end{array}$ & $\checkmark$ & 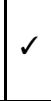 & a & & Survey & Buyer-supplier & 218 buyers & Multiple & $\begin{array}{c}\text { Not } \\
\text { specified }\end{array}$ & $\begin{array}{l}\text { An increase in procedural, distributive or interactional justice improves performance only if the specific justice } \\
\text { dimension is the bottleneck element in the relationship. All three elements of justice are essential and a high level } \\
\text { of one of the justice dimension will not compensate for a low level of another. }\end{array}$ \\
\hline \begin{tabular}{|c|} 
Praxmarer-Carus et al. \\
(2013)
\end{tabular} & $\checkmark$ & & & & Buyer-supplier & Supplier & Survey & Multiple industries & $\begin{array}{c}\text { Across } \\
\text { countries }\end{array}$ & $\begin{array}{l}\text { Suppliers' perceived share of earnings in supplier development programme enhances perceived distributive } \\
\text { justice, which positively increases supplier satisfaction with the programme. }\end{array}$ \\
\hline Duffy et al. (2013) & 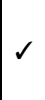 & 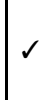 & 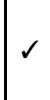 & $\checkmark$ & Supplier-retailer & Supplier & Survey & Retail & UK & $\begin{array}{l}\text { Only distributive justice increases supplier investment and engagement in buyer's customer relationship } \\
\text { management (CRM) strategy. Surprisingly, procedural justice is negatively related to supplier's engagement in } \\
\text { buyer's CRM. }\end{array}$ \\
\hline Wang et al. (2014) & $\checkmark$ & $\checkmark$ & $\checkmark$ & & Buyer-supplier & Buyer & Survey & Multiple industries & China & $\begin{array}{l}\text { Suppliers' distributive and procedural justice can recoup buyer's damaged trust in their abilities, integrity and } \\
\text { benevolence, while interactional justice can regain buyer's trust in their benevolence. }\end{array}$ \\
\hline $\begin{array}{l}\text { Poppo and Zhou } \\
\quad(2014)\end{array}$ & $\checkmark$ & $\checkmark$ & & & Buyer-supplier & Dyads & Survey & Multiple industries & China & $\begin{array}{l}\text { Procedural justice mediates the relationship between complex contracts and exchange performance, while contract } \\
\text { recurrence mediates the relationship between distributive justice and performance. }\end{array}$ \\
\hline Hoppner et al. (2014) & $\checkmark$ & $\checkmark$ & & & Buyer-seller & Seller & Survey & Multiple industries & US & Only procedural justice positively affects relationship performance. \\
\hline Liu et al. (2015) & $\checkmark$ & $\checkmark$ & a & & Buyer-supplier & Supplier & $\begin{array}{c}\text { Multiple } \\
\text { Cases }\end{array}$ & Not specified & $\begin{array}{c}\text { New } \\
\text { Zealand }\end{array}$ & $\begin{array}{l}\text { The authors developed a four-step sales process model to regain B2B customer reacquisition. In the } \\
\text { implementation step, the integration of distributive, procedural and interactional justice facilities customer } \\
\text { reacquisition. }\end{array}$ \\
\hline Luo et al. (2015) & $\checkmark$ & $\checkmark$ & a & & $\begin{array}{c}\text { Manufacturer- } \\
\text { distributor }\end{array}$ & Dyads & Survey & Home appliance & China & $\begin{array}{l}\text { Distributive justice suppresses strong form opportunism and procedural justice attenuates weak form opportunism, } \\
\text { while interactional justice alleviates both forms of opportunism, which subsequently improves relationship } \\
\text { performance and reduces governance costs. }\end{array}$ \\
\hline Kaynak et al. (2015) & $\checkmark$ & $\checkmark$ & & & $\begin{array}{l}\text { Wholesaler- } \\
\text { retailer }\end{array}$ & Retailer & Survey & Pharmaceutical & Turkey & $\begin{array}{l}\text { Distributive and procedural justice increase relationship continuity. Both distributive and procedural justice have } \\
\text { no moderating effect on the relationship between wholesaler's unethical behaviours and relationship continuity. }\end{array}$ \\
\hline Hemmert et al. (2016) & $\checkmark$ & $\checkmark$ & & & Buyer-supplier & Supplier & Survey & Multiple industries & South Korea & $\begin{array}{l}\text { Legal protection and government support increase buyer's procedural justice, whereas social networks increase } \\
\text { buyer's distributive justice. Both procedural and distributive justice, in turn, positively related to supplier's trust. }\end{array}$ \\
\hline Huo et al. (2016) & $\checkmark$ & a & a & & Buyer-supplier & Buyer & Survey & Multiple industries & China & $\begin{array}{l}\text { Supplier's procedural and distributive justice increase buyer's specific investment, whereas interactional justice } \\
\text { positively affects communication, which reduces opportunism. Only procedural justice directly curbs buyer's } \\
\text { opportunism. }\end{array}$ \\
\hline Zaefarian et al. (2016) & $\checkmark$ & $\checkmark$ & a & & \begin{tabular}{|c|}
$\begin{array}{c}\text { Manufacturer- } \\
\text { supplier }\end{array}$ \\
\end{tabular} & Supplier & Survey & Automobile & Iran & $\begin{array}{l}\text { Distributive and interactional justice increase trust and commitment, which in turn, increase sales growth. } \\
\text { Surprisingly, procedural justice has no effect on trust and commitment. }\end{array}$ \\
\hline $\begin{array}{l}\text { Trada and Goyal } \\
\text { (2017) }\end{array}$ & $\checkmark$ & $\checkmark$ & $\checkmark$ & & $\begin{array}{l}\text { Supplier- } \\
\text { distributor }\end{array}$ & Dyads & Survey & Pharmaceutical & India & $\begin{array}{l}\text { Distributive, procedural and interactional unfairness directly increase distributor opportunism and it magnified } \\
\text { with higher level of supplier investment, environmental uncertainty and behavioural uncertainty. }\end{array}$ \\
\hline
\end{tabular}




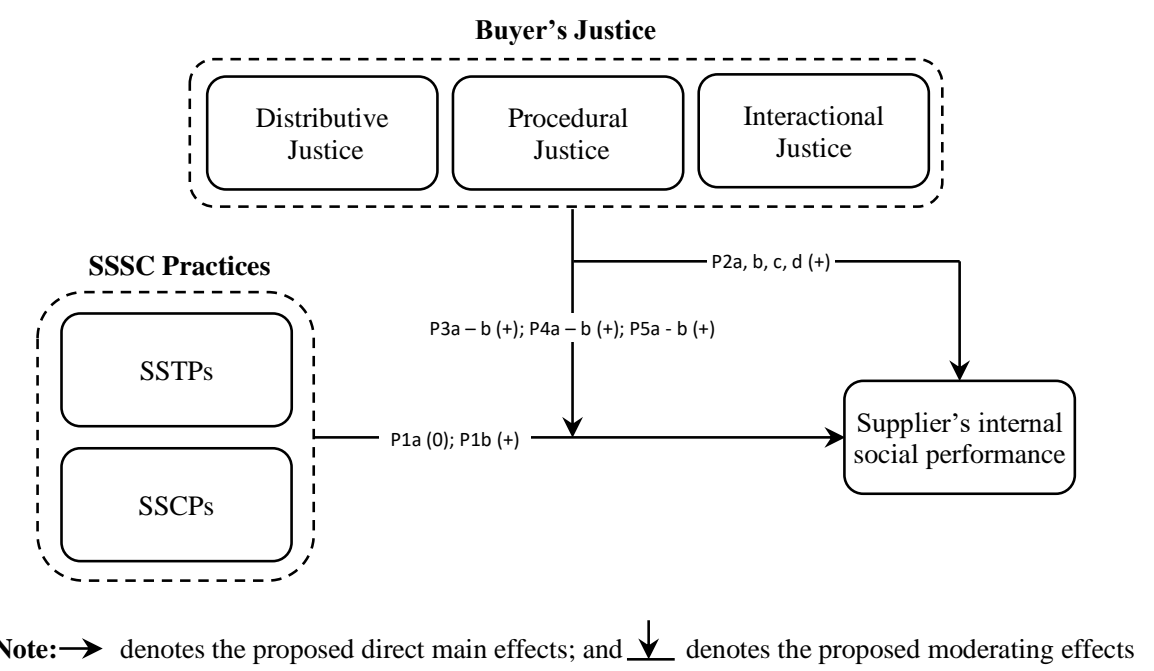

Figure (1): A conceptual model of the role of justice in the implementation of sustainable supply chain management 